\title{
Coprophilous discomycetes from the Tuscan archipelago (Italy). Description of two rare species and a new Trichobolus
}

\section{Doveri $F^{*}$}

Via dei Funaioli 22, I-57126-Livorno.

Doveri F. 2012 - Coprophilous discomycetes from the Tuscan archipelago (Italy). Description of two rare species and a new Trichobolus. Mycosphere 3(4), 503-522, Doi 10.5943 /mycosphere/3/4/13

With this article the author begins a survey of coprophilous Ascomycetes and Basidiomycetes from the Tuscan archipelago, explaining the reasons why this area has so scarcely been explored so far. After collecting samples of wild rabbit dung and amazing at their productiveness, he describes and analyzes two uncommon discomycetes, and introduces a new species of Trichobolus with 8-spored asci. Finally he stresses the difficulties in distinguishing the 8-spored species of Trichobolus from some Lasiobolus and provides a key to them.

Key words - Chalazion erinaceum - Coprotus dextrinoideus - dextrinoid setae - rabbit dung Trichobolus dextrinoideosetosus.

\section{Article Information}

Received 6 July 2012

Accepted 24 July 2012

Published online 29 August 2012

*Corresponding author: Francesco Doveri - e-mail - f.doveri@ sysnet.it

\section{Introduction}

My survey on coprophilous fungi from Italy has resulted in several articles since 1995 (Cacialli et al.) and culminated in a monograph on Basidiomycetes and Ascomycetes (Doveri 2004) and in its update (Doveri 2011). My studies have covered wide areas of most Italian regions, but some are still unexplored either for fortuitous reasons or especially for restrictions of free admission.

The Tuscan archipelago is one of the less explored areas for fungal diversity. It is formed of seven major islands and some isles and rocks placed in the nothern Tirreno sea between Corsica island and the shore of the Tuscan provinces of Livorno and Grosseto (Fig. 1). It is the largest marine park of the Mediterranean Sea and also of Europe, an area where almost 60,000 sea- and 20,000 land hectares are protected. Some islands (Capraia, Elba, Giglio) are strongly anthropized and live particularly on summer tourism, but to others
(Gorgona, Pianosa) the admission is partly or not allowed at all, as places of penal colonies, and for others the environmental protection is absolute and the admission permits hard to obtain. Some animal species are endemic to these islands (e.g. the Montecristo goat and viper) and many live in a wild state. Only recently I have begun studying dung of numerous wild rabbit colonies living in Giglio Island, being amazed at their very high fungal production. According to Richardson (2001) the species richness has a mean number of 912 per mammalian dung sample (rabbit included), but I have a slightly lower mean for my Italian samples, so the 18 species (17 ascomycetes, 1 basidiomycete) that I found on a sample of wild rabbit dung are an exception. Three discomycetes particularly drew my attention, Chalazion erinaceum as a second collection worldwide, Coprotus dextrinoideus as a rare species new to Italy, and Trichobolus sp., whose unique morphology allows me to 


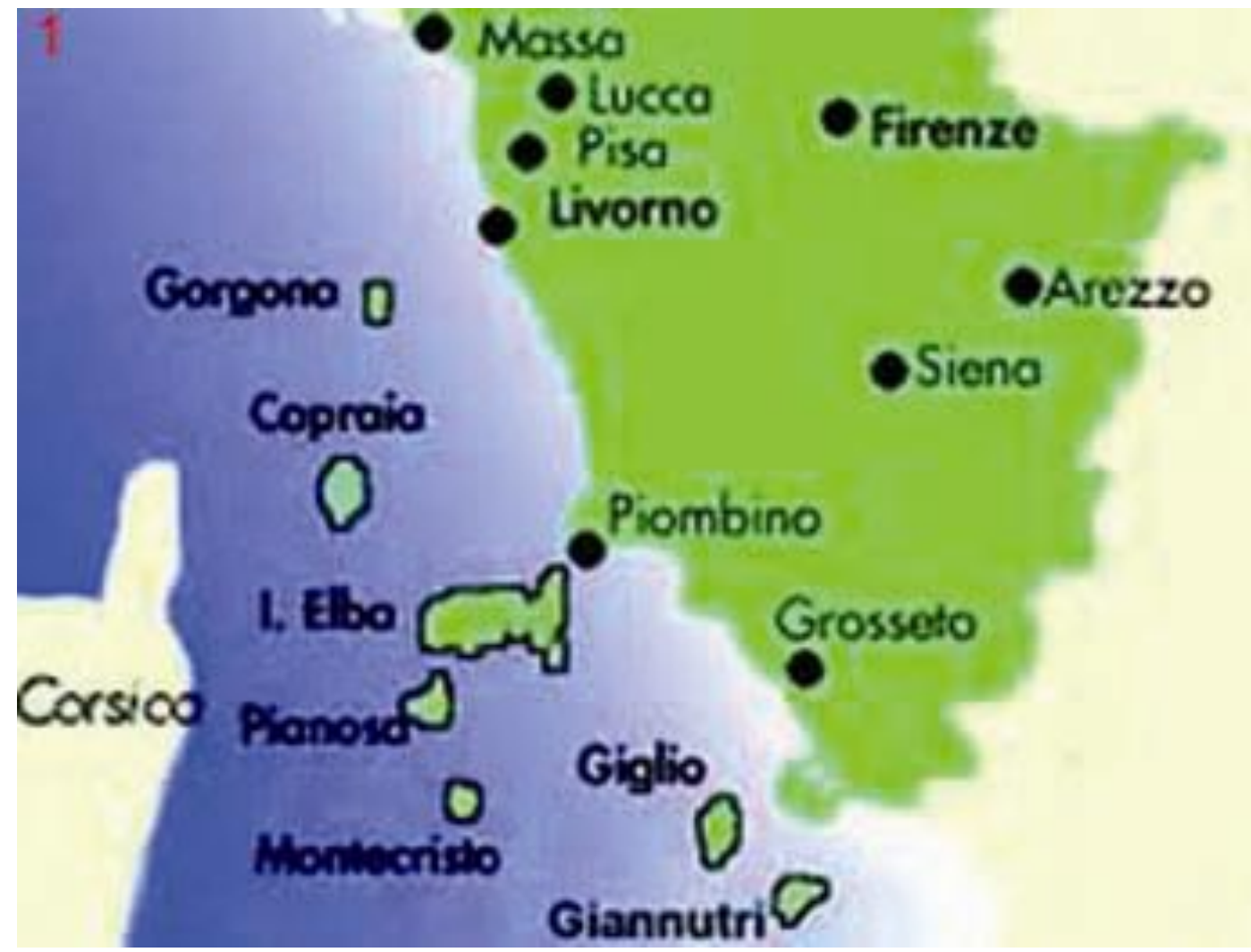

Fig. 1 - Map of the Tuscan archipelago.

erect a new taxon and call it Trichobolus dextrinoideosetosus. The aim of this work is to lay the base of a new survey on coprophilous fungi from the Tuscan archipelago, describing and analysing thoroughly two very rare fungi, and defining a new species and its relationships within Trichobolus, and with some 8-spored species of Lasiobolus.

\section{Methods}

Most isolates were obtained from wild rabbit droppings collected in Giglio Island and placed in a non-sterilised damp chamber, following the methods suggested by Richardson \& Watling (1997) and Richardson (2001), slightly modified by Doveri (2004).

Cultured material, incubated at room temperature $\left(18-25{ }^{\circ} \mathrm{C}\right)$ under natural light but not exposed to direct sunlight, was examined every day and for 5 weeks with a stereomicroscope.

Mature ascomata of Coprotus dextrinoideus and Trichobolus dextrinoideosetosus were noticed after 18-20 days' incubation and of Chalazion erinaceum a few days later. Ascomata were picked up from dung by a sterile needle.
Microscopic examinations were carried out on fresh material, mounting specimens in water, Melzer's reagent, Congo red and methyl blue or cotton blue in lactic acid. Spore length and breadth were calculated in water on 20 ascospores at least, discharged from mature asci, excluding ornamentations from measurements. The notation $[52,5,1]$ means that 52 ascospores were measured from 5 specimens of 1 collection. Q means the quotient of spore length divided by the breadth in face view.

The collections have been preserved as dried material and slides in the author's personal herbarium (CLSM) or in MCVE. Herbarium abbreviation follows Holmgren \& Holmgren (1998).

\section{Taxonomy}

Chalazion erinaceum Doveri, Y.Z. Wang, Cacialli \& Caroti, Rivista di Micologia 41: 204, 1998. Figs 2-11

MB446402

Ascomata 75-150 $\mu \mathrm{m}$ diam., 50-100 $\mu \mathrm{m}$ high, barrel-shaped to subcylindrical and translucent white at first, becoming discoidal or pulvinate and dirty whitish, membranous, 




Figs 2-3 - Chalazion erinaceum. CLSM 05998 bis. 2 Ascoma on dung 3 Detail of excipulum in Congo red. Bars $2=50 \mu \mathrm{m}, 3=15 \mu \mathrm{m}$.

smooth, with an even, scarcely to well differentiated margin and a hymenial surface of the same colour, dotted at maturity due to the protruding asci. Medullary excipulum not well differentiated from the ectal excipulum, the latter strongly cyanophilic and congophilous, a textura angularis of hyaline, thick-walled, polygonal cells, 4-9 $\mu \mathrm{m}$ diam., a textura prismatica towards the margin, with cylindrical cells perpendicular to the hymenial surface, often globose or clavate at the ends. Paraphyses 1-2 $\mu \mathrm{m}$ diam., cylindric-filiform, somewhat enlarged at the tips, up to $4 \mu \mathrm{m}$ diam., simple or sometimes branched at the base, often slightly curved at the apex, septate, containing some hyaline vacuoles, slightly exceeding the asci. Asci $60-70 \times 25-35 \mu \mathrm{m}$, broadly clavate, non-amyloid, congophilous, unitunicate, operculate, 8-spored, thick-walled, rounded at the apex, abruptly contracted below in a short, lobate stalk. Ascospores bi- or triseriate inside the asci, (13.5-) 14-17.5 (-18) $\times(9.5-)$ 10-12 $\mu \mathrm{m}$ (ornamentations excluded), ellipsoidal $(\mathrm{Q}=1.33-1.76$; average $\mathrm{Q}=1.47$; 1.57 in the second collection), hyaline, thick- walled, lacking a gelatinous perisporium, smooth and usually with a large oil drop or with a droplet and a larger drop when young, becoming verrucose with roundish, strongly cyanophilic, isolated or sometimes merging warts, $0.5-2.5 \mu \mathrm{m}$ diam., 0.5-2 $\mu \mathrm{m}$ high.

Material examined - Italy, Grosseto, Punta Ala, $0 \mathrm{~m}$ a.s.l., eleven gregarious, superficial specimens on hedgehog dung in culture, F. Doveri and F. Bersan, 2.4.98, 318.3-Punta Ala, MCVE 706; Grosseto, Giglio Island, Castello, $400 \mathrm{~m}$ a.s.l., about twenty specimens on wild rabbit dung in culture, S. Rum, 22.3.12, 352.4-Giglio, CLSM 05998 bis.

Notes - The description above concerns my second collection from wild rabbit dung, which has morphological features practically superimposable to the first, except for the somewhat larger spore length/breadth ratio (average $\mathrm{Q}=1.57$ versus 1.47 ).

The microscopic features of $C$. erinaceum were drawn freehand in the protologue (Doveri et al. 1998) and in a subsequent work (Doveri 2004), and only a black and white photo of one ascus with 


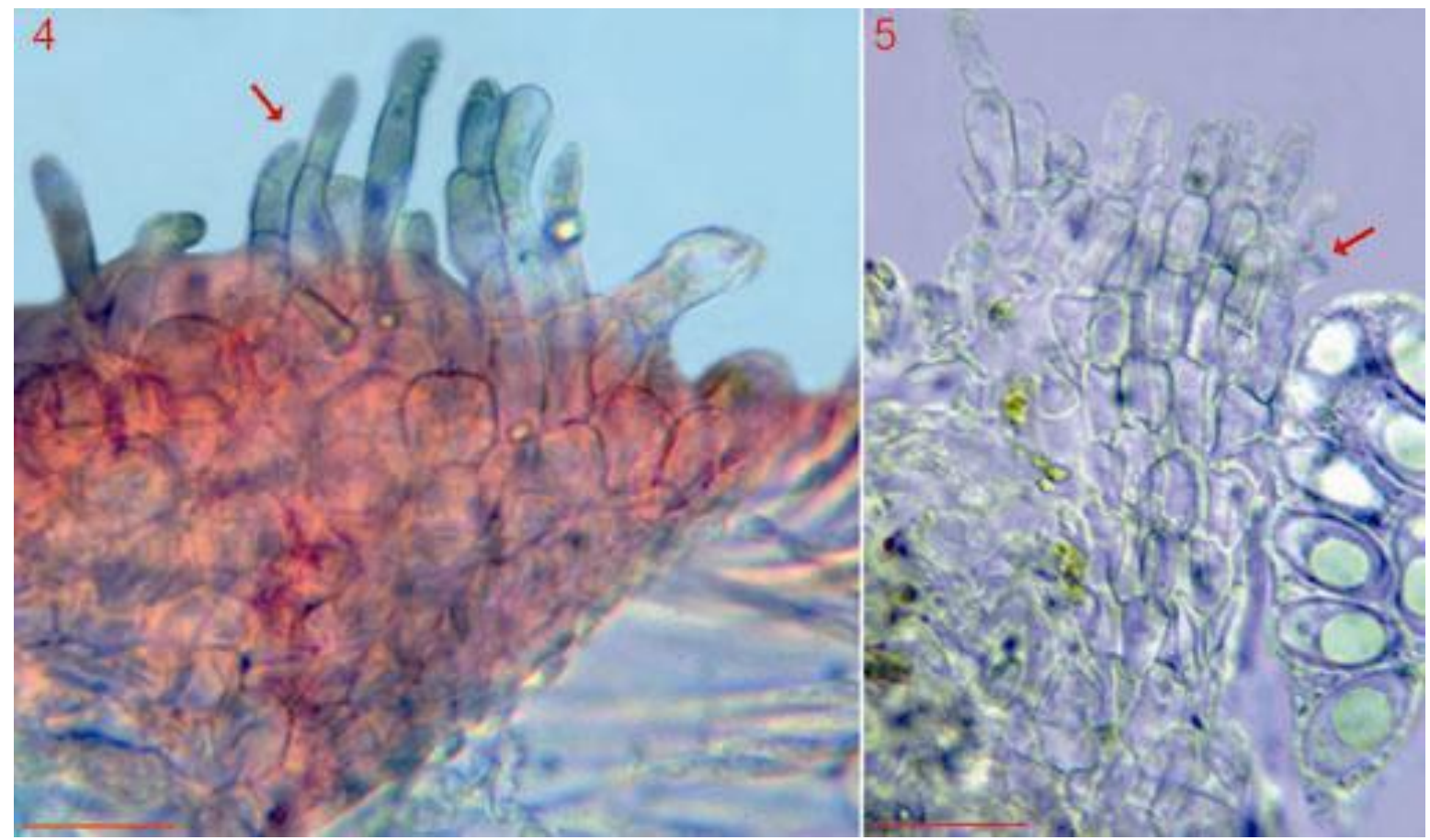

Figs 4-5 - Chalazion erinaceum. CLSM 05998 bis. 4 Terminal cells of excipulum in Congo red (arrow) 5 Textura prismatica of the marginal excipulum (water). Bars $4=10 \mu \mathrm{m}, 5=20 \mu \mathrm{m}$.

ascospores was also shown in the protologue. This second finding gives me the opportunity to provide the first detailed colour photos both of macro- and microscopic features.

The very rare $C$. erinaceum (only two findings in 15 years), appears to be restricted to a small area of Tuscany (Italy). It is the only coprophilous Chalazion and the latest published species after $C$. sociabile Dissing \& Sivertsen (1975) and C. helveticum Dissing (1980), a key to which is provided in my previous works (Doveri et al. 1998, Doveri 2004). I also refer to these papers and Lumbsch \& Huhndorf (2010) for the taxonomic position of Chalazion Dissing \& Sivertsen in Pyronemataceae Corda (Pezizales J. Schröt.).

Coprotus dextrinoideus Kimbr., Luck-Allen \& Cain, Can. J. Bot. 50: 962, 1972. Figs 12-20 MB311762

Apothecia sessile, subglobous to subcylindric at first, becoming discoidal, 100$280 \mu \mathrm{m}$ diam., whitish, soon pale yellow, membranous, smooth, with a darker yellow, slightly prominent margin. Hymenial surface dotted at maturity due to the protruding asci, pale yellow. Subhymenium and medullary excipulum indistinguishable from the ectal excipulum, the latter cyanophilic and strongly dextrinoid, a textura globulosa in the lower part of the ascoma, a textura globulosaangularis in the middle, made up of slightly thick-walled, yellowish, polygonal or subglobose cells, 3-10 × 3-8 $\mu \mathrm{m}$, cylindrical towards the apothecial margin, often somewhat wavy and subcapitate, thick-walled, darker yellow, 7-17 × 3-4 $\mu \mathrm{m}$. Paraphyses cylindricfiliform, $1-1.5 \mu \mathrm{m}$ diam., simple or branched (usually at the base), exceeding the asci, septate, containing many pale yellow vacuoles, slightly uncinate, hardly inflated at the tips. Asci slightly congophilous, 8-spored, unitunicate, operculate, non-amyloid, cylindric or broadly cylindric, $80-100 \times 16-20 \mu \mathrm{m}$, short-stalked, slightly flattened at the apex. Ascopores uniseriate at first, uni- or biseriate later, one-celled, 11-13 (-13.5) × (6.5-) 7-8 (8.5) $\mu \mathrm{m}$, ellipsoidal $(\mathrm{Q}=1.50-1.76$; average $\mathrm{Q}$ $=1.62$ ), with subacute ends, thick-walled in the early stages, pale yellow, smooth, containing a large de Bary bubble in aqueous media.

Material examined - Italy, Grosseto, Giglio island, Castello, $400 \mathrm{~m}$ a.s.1., about twenty scattered or gregarious, superficial specimens, on wild rabbit dung in a damp chamber culture, S. Rum, 22.3.12, 352.4Giglio, CLSM 002.12. 

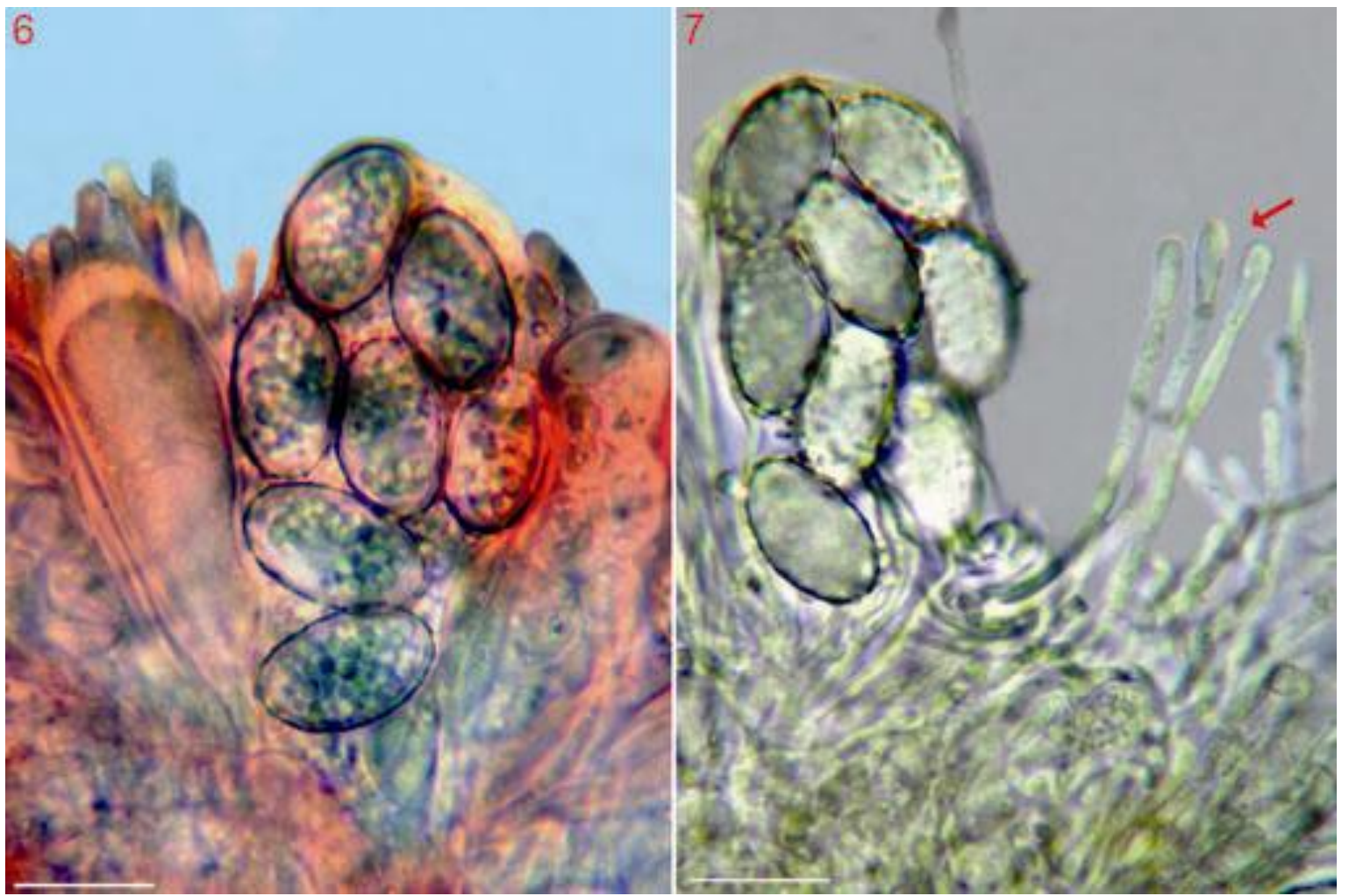

Figs 6-7 - Chalazion erinaceum. CLSM 05998 bis. Paraphyses (arrow) mixed with mature and immature asci. Bars $=12 \mu \mathrm{m}$.
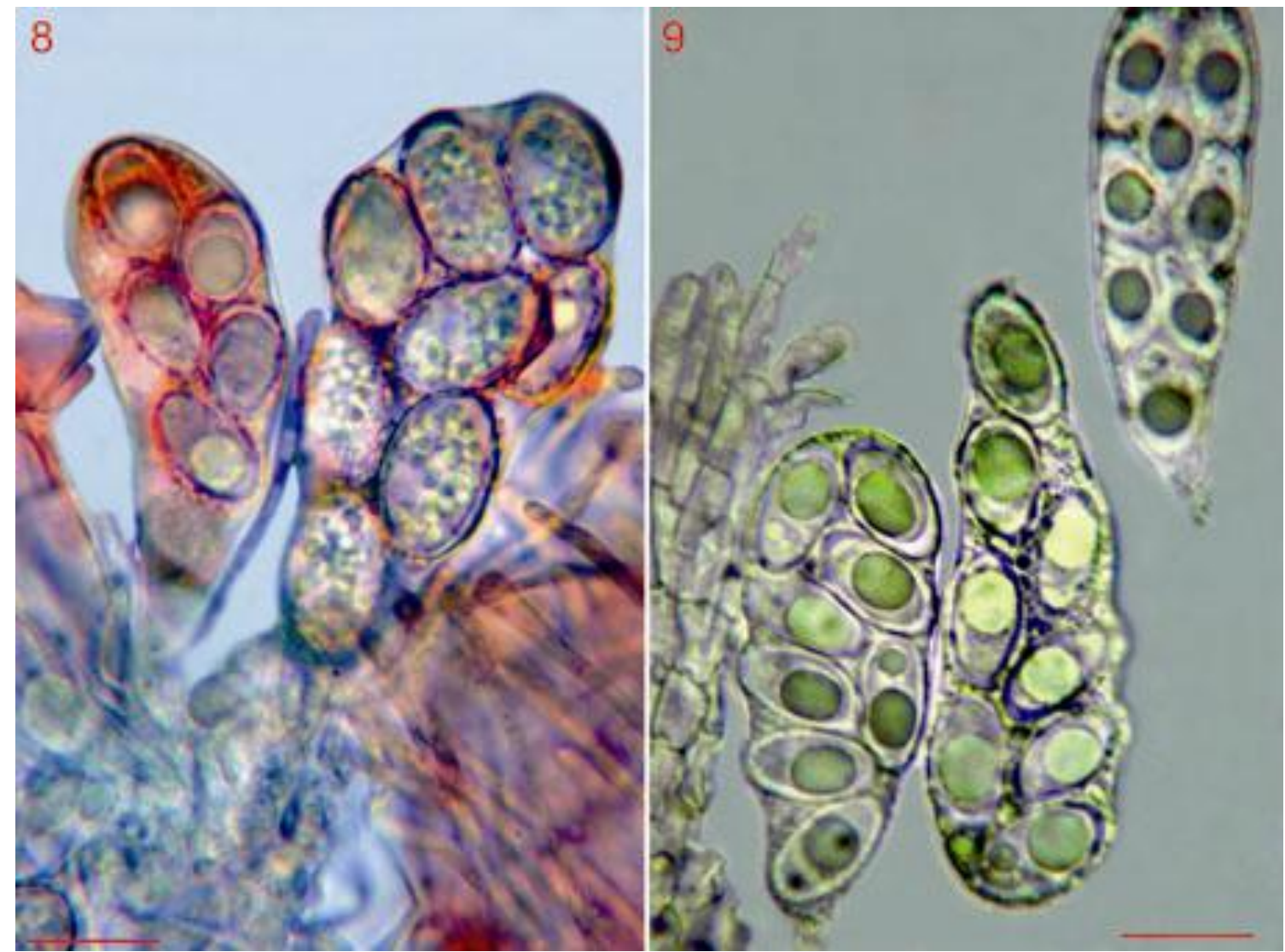

Figs 8-9 - Chalazion erinaceum. CLSM 05998 bis. 8 Asci with ascospores in different stages of maturity (Congo red) 9 Immature ascospores inside asci and detail of the marginal excipulum (water). Bars $=12 \mu \mathrm{m}$. 

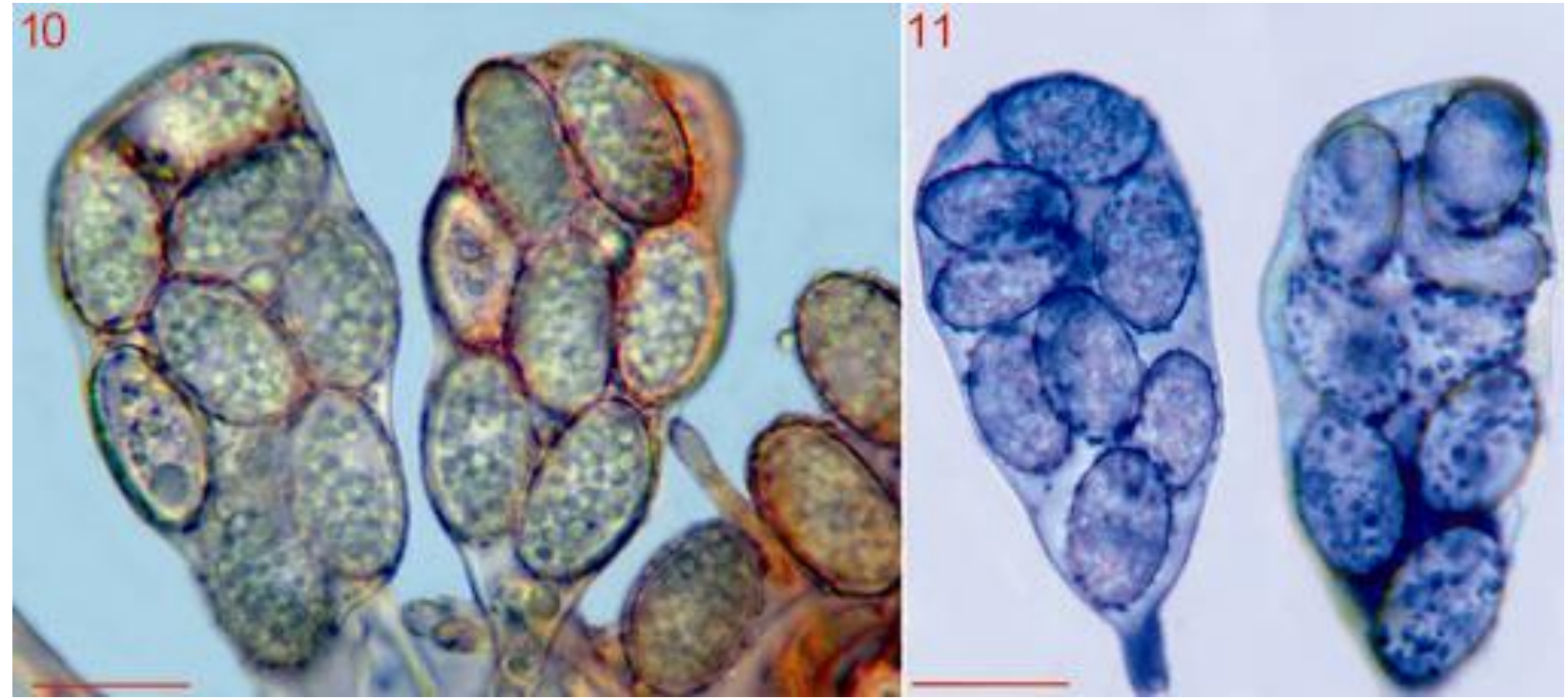

Figs 10-11 - Chalazion erinaceum. CLSM 05998 bis. 10 Mature ascospores inside asci and some free ascospores (Congo red) 11 Ascospores with strongly cyanophilic warts inside asci (cotton blue in lactic acid). Bars $10=12 \mu \mathrm{m}, 11=15 \mu \mathrm{m}$.


Figs 12-14 - Coprotus dextrinoideus. CLSM 00212. 12 Apothecia on dung 13 Yellowish excipular cells (water) 14 Detail of excipulum (Congo red). Bars $12=150 \mu \mathrm{m}, 13=20 \mu \mathrm{m}, 14=15 \mu \mathrm{m}$. 

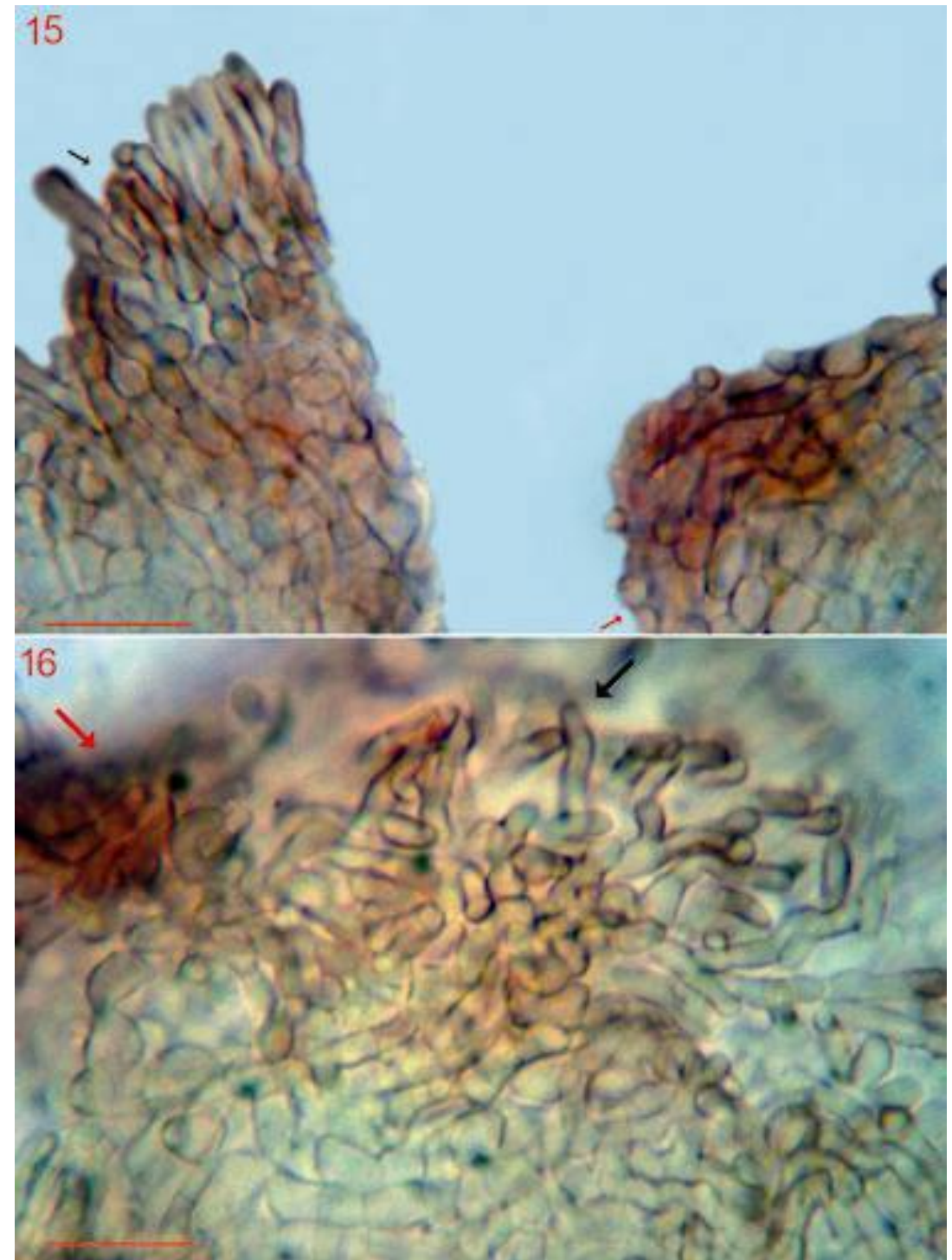

Figs 15-16 - Coprotus dextrinoideus. CLSM 00212. 15 Dextrinoid reaction of the middle (red arrow) and marginal (black arrow) excipulum 16 Dextrinoid reaction (red arrow) of the marginal excipulum with wavy terminal cells (black arrow). Bars $=20 \mu \mathrm{m}$.

Notes - Coprotus [Thelebolales P.F. Cannon, Thelebolaceae (Brumm.) Eckblad] was erected by Korf \& Kimbr. (in Kimbrough \& Korf 1967) to accommodate coprophilous species with minute, discoidal apothecia, 8 to polyspored, operculate, non-amyloid, congophilous asci protruding at maturity, and hyaline, ellipsoidal ascospores containing a de Bary bubble in aqueous media.

The genus was subsequently monographed by Kimbrough et al. (1972), who accepted and described 18 species, subdivided in two groups, the former with pigmented (yellow to orange) apothecia and paraphyses (containing carotenoids), the latter with whitish apothecia, becoming pale yellow with age or drying, and paraphyses lacking carotenoids. In the latter group a subgroup was recognised with an excipulum (particularly at the margin) of thick-walled, strongly cyanophilic and dextrinoid cells. C. dextrinoideus belongs to it.

We described some Coprotus spp. from Italy (Cacialli et al. 1996 a, b, Doveri et al. 2000) and I also provided a worldwide dichotomous key to the genus (Doveri 2004), based on Kimbrough et al. (1972) but updated to encompass eight species published after them. Since then no new Coprotus sp. has been published.

According to Kimbrough et al. (1972) C. dextrinoideus is similar to $C$. disculus Kimbr. et al., but the former has broadly rather than narrowly ellipsoidal ascospores, a more yellow pigmented excipulum with thicker cells 


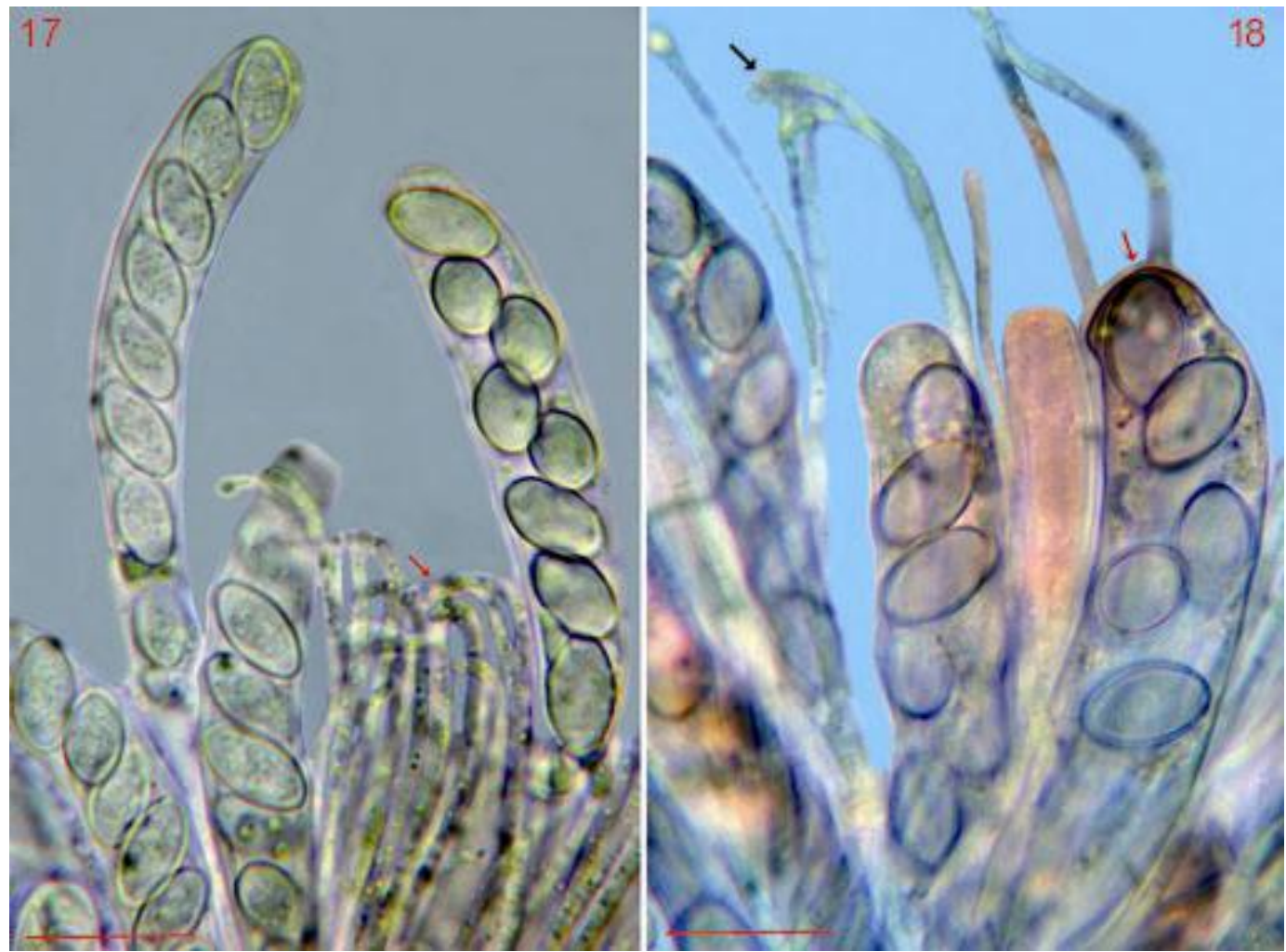

Figs 17-18 - Coprotus dextrinoideus. CLSM 00212. 17 Protruding asci in water and apices of paraphyses (arrow) 18 Paraphyses (black arrow) and asci (red arrow) with operculate, slightly flattened apices (Congo red). Bars $17=20 \mu \mathrm{m}, 18=15 \mu \mathrm{m}$.


Figs 19-20 - Coprotus dextrinoideus. CLSM 00212. 19 Ascospores with subacute ends (arrow) inside the asci (Congo red) 20 Mature ascus (arrow) with ascospores containing a de Bary bubble in lactic cotton blue. Bars $=15 \mu \mathrm{m}$. 


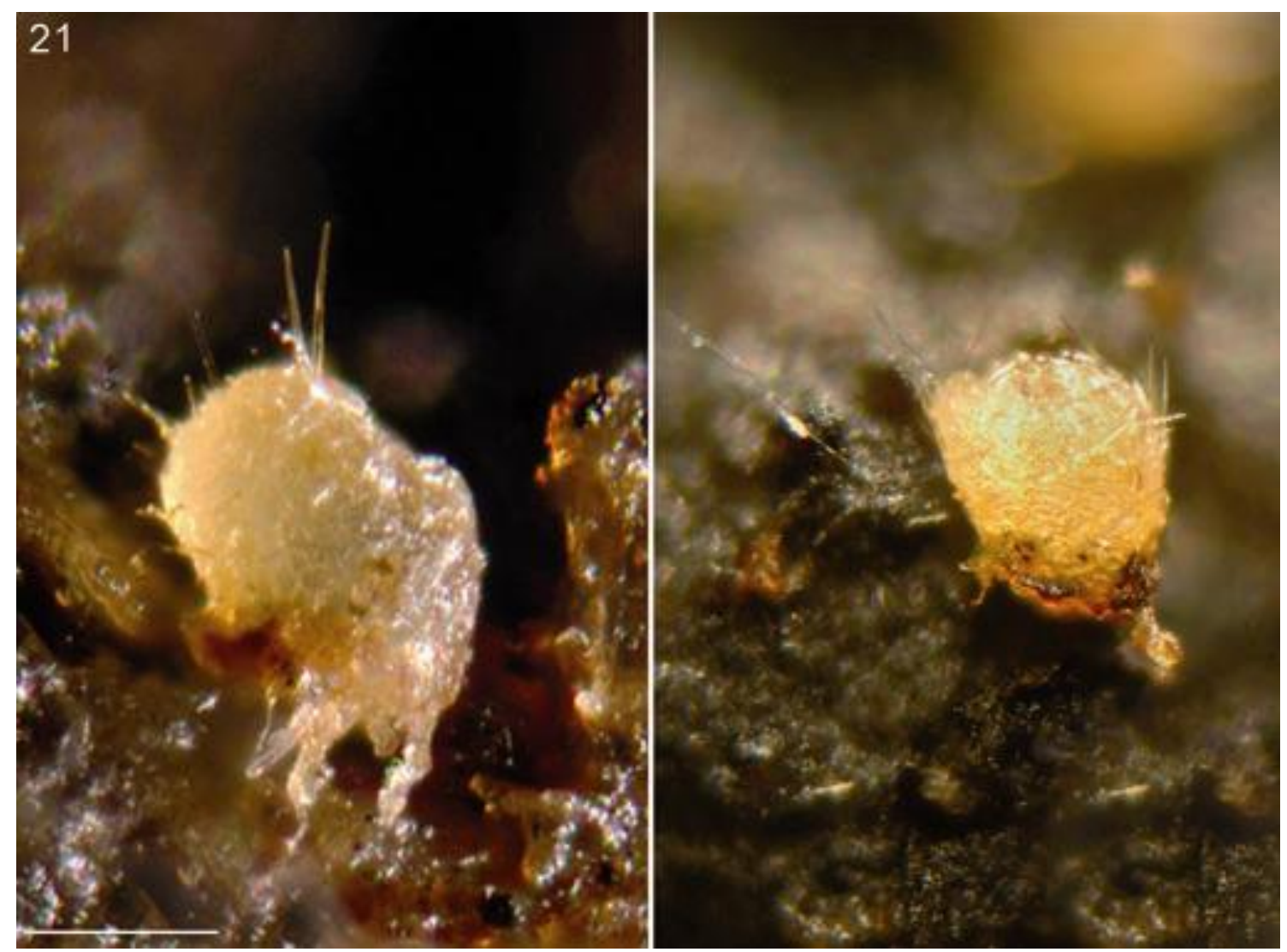

Fig 21 - Trichobolus dextrinoideosetosus. MCVE 27398. 21 Ascomata on dung. Bar = $200 \mu \mathrm{m}$.
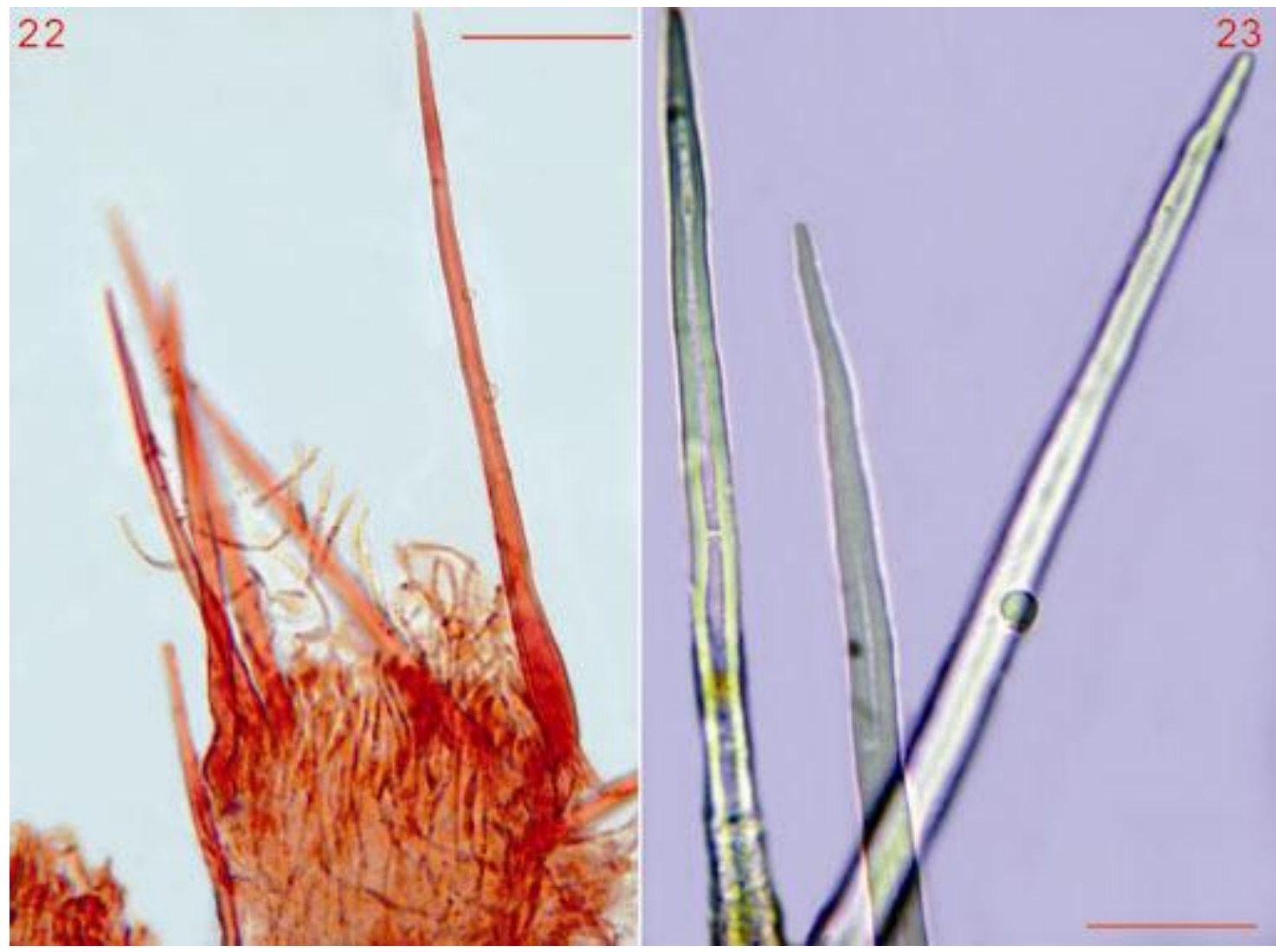

Figs 22-23 - Trichobolus dextrinoideosetosus. MCVE 27398. 22 Ascoma with straight, pointed setae (Congo red) 23 Apices of setae (water). Bars $22=50 \mu \mathrm{m}, 23=10 \mu \mathrm{m}$. 
and longer marginal cells, and paraphyses containing oil drops. We have observed only slightly narrower ascospores in our Italian collections of C. disculus (average length/breadth ratio 1.72 versus 1.62 ), besides we have noticed an additional difference between the two species, i.e. slightly concave, rather than rounded spore ends in $C$. dextrinoideus. This feature was not mentioned in either the protologue or in other publications, but it was drawn by Moyne \& Petit (2006-2007) in some ascospores of their collection.

The collection described by Prokhorov \& Kutorga (1990) has too narrow asci and small ascospores in comparison with the protologue, whereas the measurements reported by Richardson (2008) for the species he called "cf. dextrinoideus" appear to fall in the variability range of the true $C$. dextrinoideus. $C$. dextrinoideus is a rare but widespread species, recorded so far from North- and Central America (Kimbrough et al. 1972), Europe (Prokhorov 1989, 1991, Prokhorov \& Kutorga 1990, Kutorga 2000, Moyne 2006, Moyne \& Petit 2006) and Middle Asia (Kimbrough et al. 1972, Raitviir \& Prokhorov 1988, Abdullah \& Alutbi 1994), particularly from cattle dung (Kimbrough et al. 1972, Raitviir \& Prokhorov 1988, Prokhorov 1989, Abdullah \& Alutbi 1994). Mine is the first record from Italy and from wild rabbit dung.

Trichobolus dextrinoideosetosus Doveri, sp. nov.

MB800713

Figs 21-39

Ascomata cleistohymenial, barrelshaped to subcylindrical in the early stages, opening in a late stage and becoming shallowcupulate, membranous, 250-350 $\mu \mathrm{m}$ high, 200-350 $\mu \mathrm{m}$ diam. Outer surface pale yellow, slightly wrinkled, hairy owing to the presence of sparse, pale setae, arising from the middle and upper part of the receptacle, running upwards or sometimes laterally turned. Hymenial surface flat to slightly concave, the same colour, dotted. Margin scarcely differentiated, glabrous. Subhymenium not differentiated from the medullary excipulum, the latter very thin, a textura angularis of hyaline, thin-walled, polygonal cells, 4-7 ×4$5 \mu \mathrm{m}$. Ectal excipulum thin, yellowish, congophilous, not dextrinoid, a textura angularis at the lower part of receptacle, formed of comparatively thick-walled, polygonal cells, 8-16 $\times 5-9 \mu \mathrm{m}$, a textura angularis to epidermoidea in the middle and upper part, sometimes prismatica on the flanks of receptacle with cells perpendicular to the hymenial surface. The base is covered with a thick net of hyphoid hairs (rhizoids or anchoring hyphae), hyaline, strongly dextrinoid, very long, flexuous, thin-walled, septate, ramified, sometimes anastomosed, 3-5 $\mu \mathrm{m}$ diam. Hairs 65-175 (-200) $\times 5-12 \mu \mathrm{m}$ (at their base), superficial, seta-like, acicular, pointed, usually straight, sometimes slightly curved, pale yellowish, strongly dextrinoid, rarely non-septate, usually with 1-3 (-5) septa, thick-walled $(1.5-2.5 \mu \mathrm{m})$, with a polymorph, enlarged but rarely slightly bulbous base, sometimes with hints of roots. Paraphyses abundant, exceeding the asci, 1.5-3 $\mu \mathrm{m}$ diam., cylindric-filiform, curved, not or slightly enlarged at the apex, simple or branched at some level, septate, containing pale yellow vacuoles. Asci numerous, non-amyloid, congophilous, 8-spored, 95-120 × (20-) 25-35 $\mu \mathrm{m}$, claviform, sometimes cylindric-claviform, thick-walled, with a rounded, operculate apex and a short, sometimes lobate stalk. Ascospores [52, 5, 1] 14-18 × 9-11 $\mu \mathrm{m}$ (mean $16 \times 10 \mu \mathrm{m})$, uniseriate in the early stages, becoming biseriate, one-celled, ellipsoidal $(\mathrm{Q}=$ 1.42-177; average $\mathrm{Q}=1.57$ ) with roundish poles, smooth, hyaline, thick-walled, with one nucleus and yellowish contents, lacking a gelatinous perisporium, oil drops and de Bary bubbles.

Material examined - Italy, Bolzano, Valle Aurina, $1300 \mathrm{~m}$ a.s.l., about forty, superficial, scattered or gregarious specimens on red deer dung in a damp chamber culture, A. Bizzi, 16.7.11, 003.3-Aurina (MCVE 27398, holotype); Grosseto, Giglio Island, Castello, $400 \mathrm{~m}$ a.s.l., about fifteen scattered specimens on wild rabbit dung in a damp chamber culture, Rum S., 22.3.12, 352.4Giglio (CLSM 001.12 bis, paratype).

Notes - Saccardo (1892) established Trichobolus as section (or subgenus) of Thelebolus Tode to accommodate species with setulose ascomata, and placed those with glabrous ascomata in section Eu-Thelebolus. 
Mycosphere Doi 10.5943/mycosphere/3/4/13
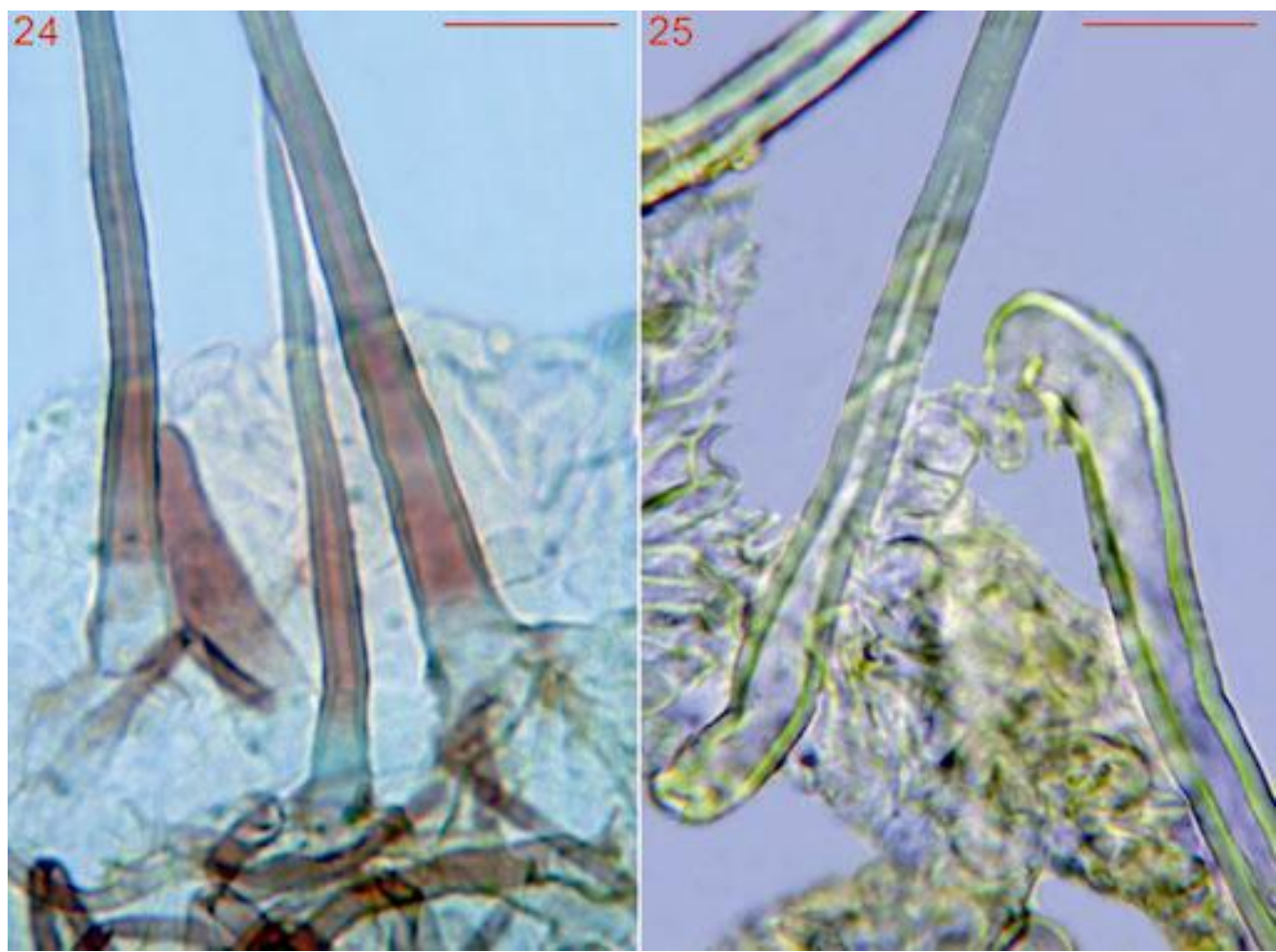

Figs 24-25 - Trichobolus dextrinoideosetosus. MCVE 27398. 24 Strongly dextrinoid setae and hyphoid hairs 25 Basal portion of setae (water). Bars $=20 \mu \mathrm{m}$.

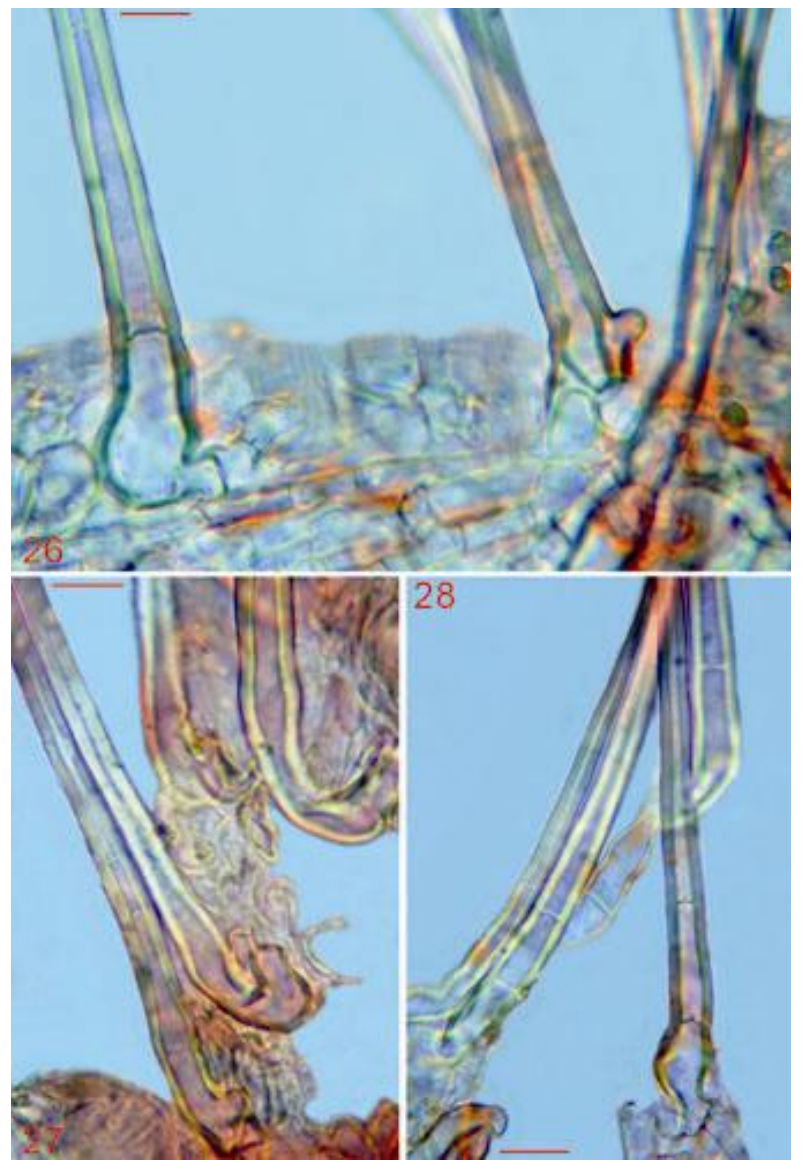

Figs 26-28 - Trichobolus dextrinoideosetosus. MCVE 27398. Basal and middle portions of setae (Congo red). Bars $26=8 \mu \mathrm{m}, 27-28=15 \mu \mathrm{m}$. 
Mycosphere Doi 10.5943/mycosphere/3/4/13

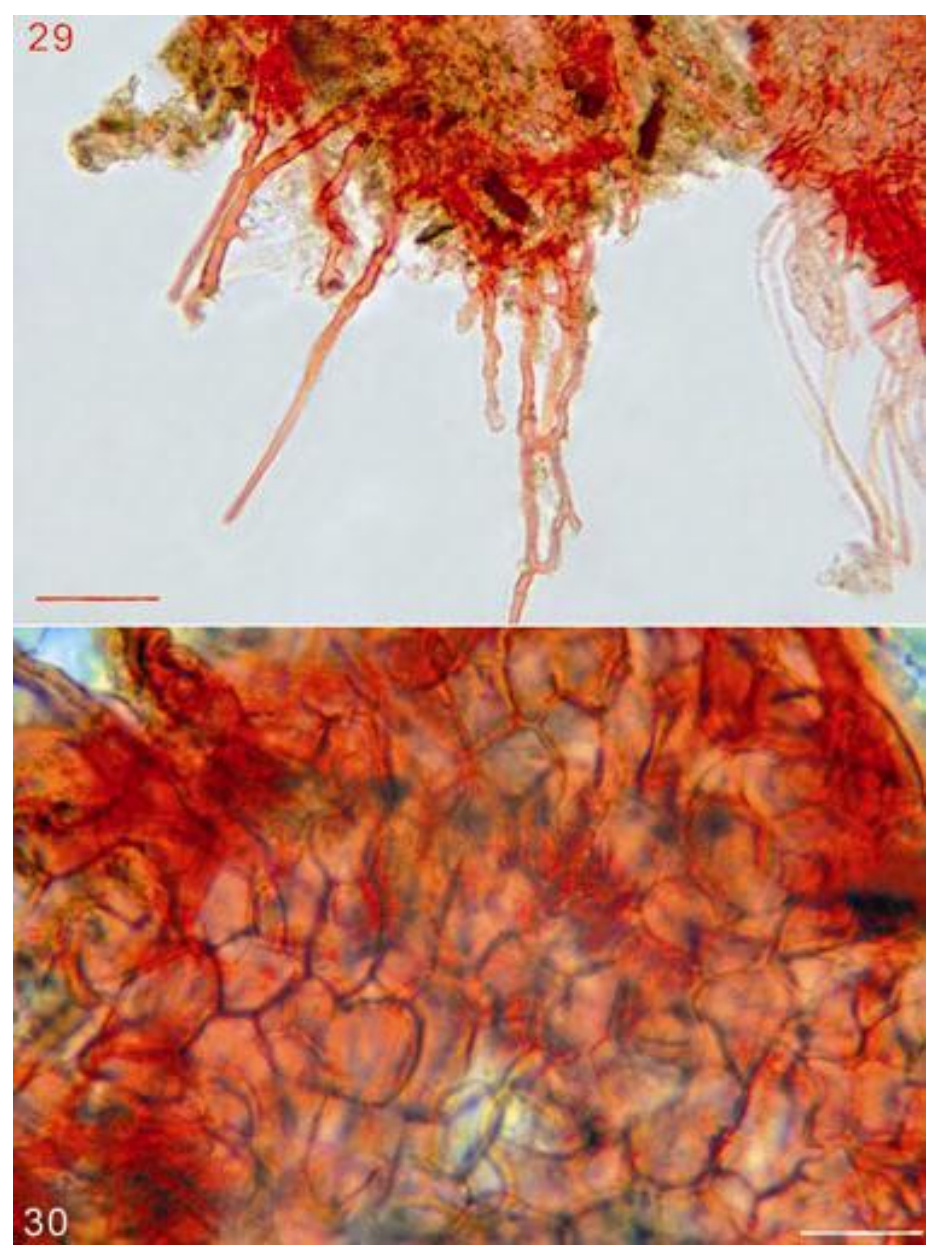

Figs 29-30 - Trichobolus dextrinoideosetosus (Congo red). MCVE 27398. 29 Basal hyphoid hairs 30 Textura angularis of the basal excipulum. Bars $29=40 \mu \mathrm{m}, 30=15 \mu \mathrm{m}$.

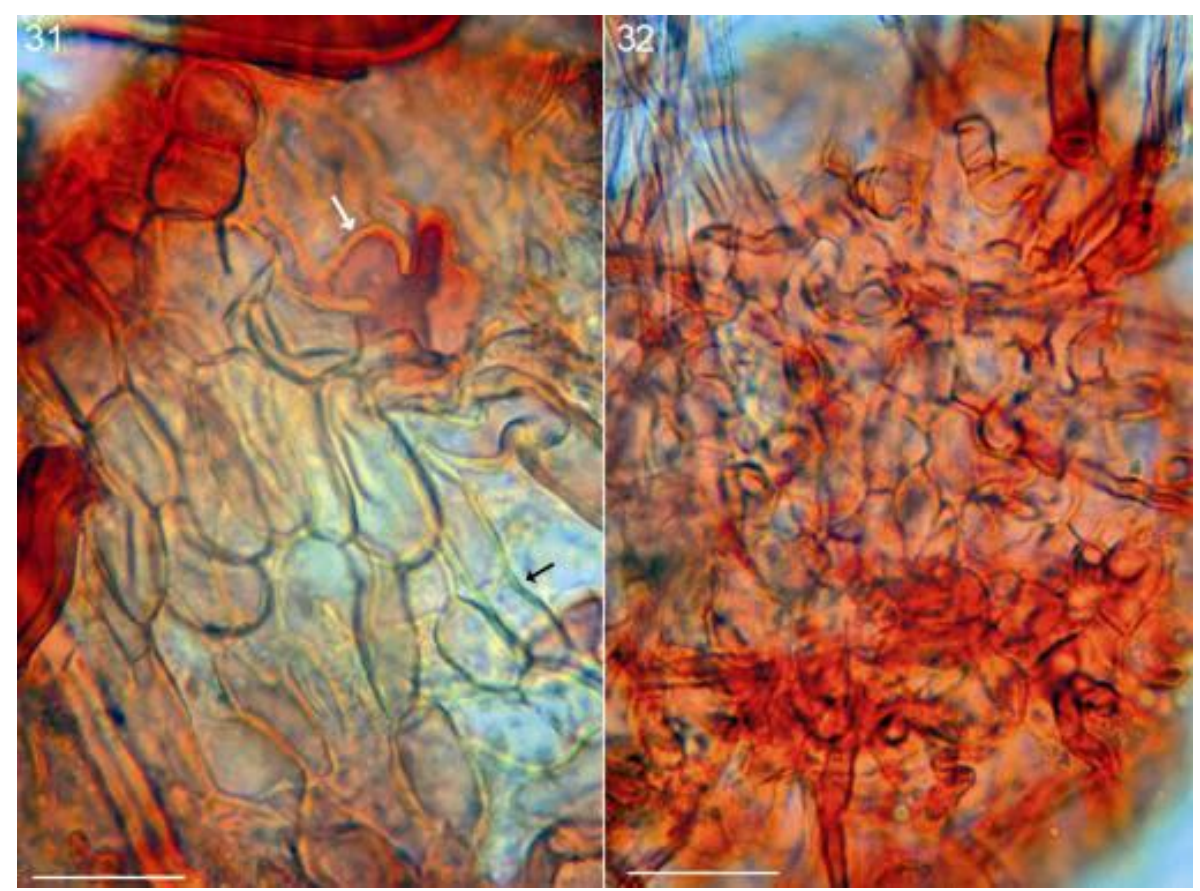

Figs 31-32 - Trichobolus dextrinoideosetosus (Congo red). MCVE 27398. 31 Textura prismatica of the marginal excipulum (black arrow) with some epidermoid cells (white arrow) 32 Epidermoid stretch of the excipulum. Bars $31=15 \mu \mathrm{m}, 32=20 \mu \mathrm{m}$. 


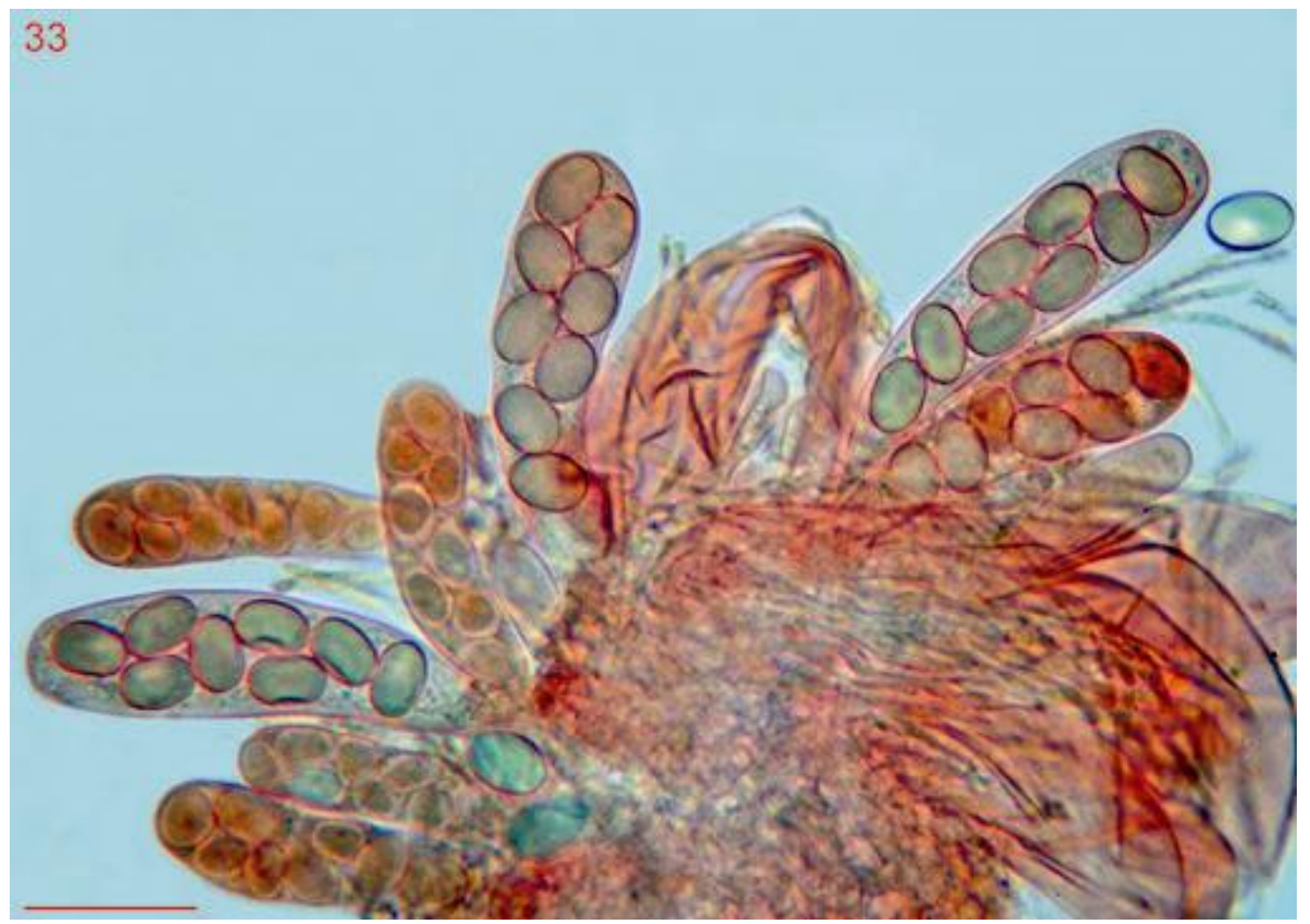

Figs 33 - Trichobolus dextrinoideosetosus. MCVE 27398. Overall view of the hymenium (Congo red). $\operatorname{Bar}=15 \mu \mathrm{m}$.

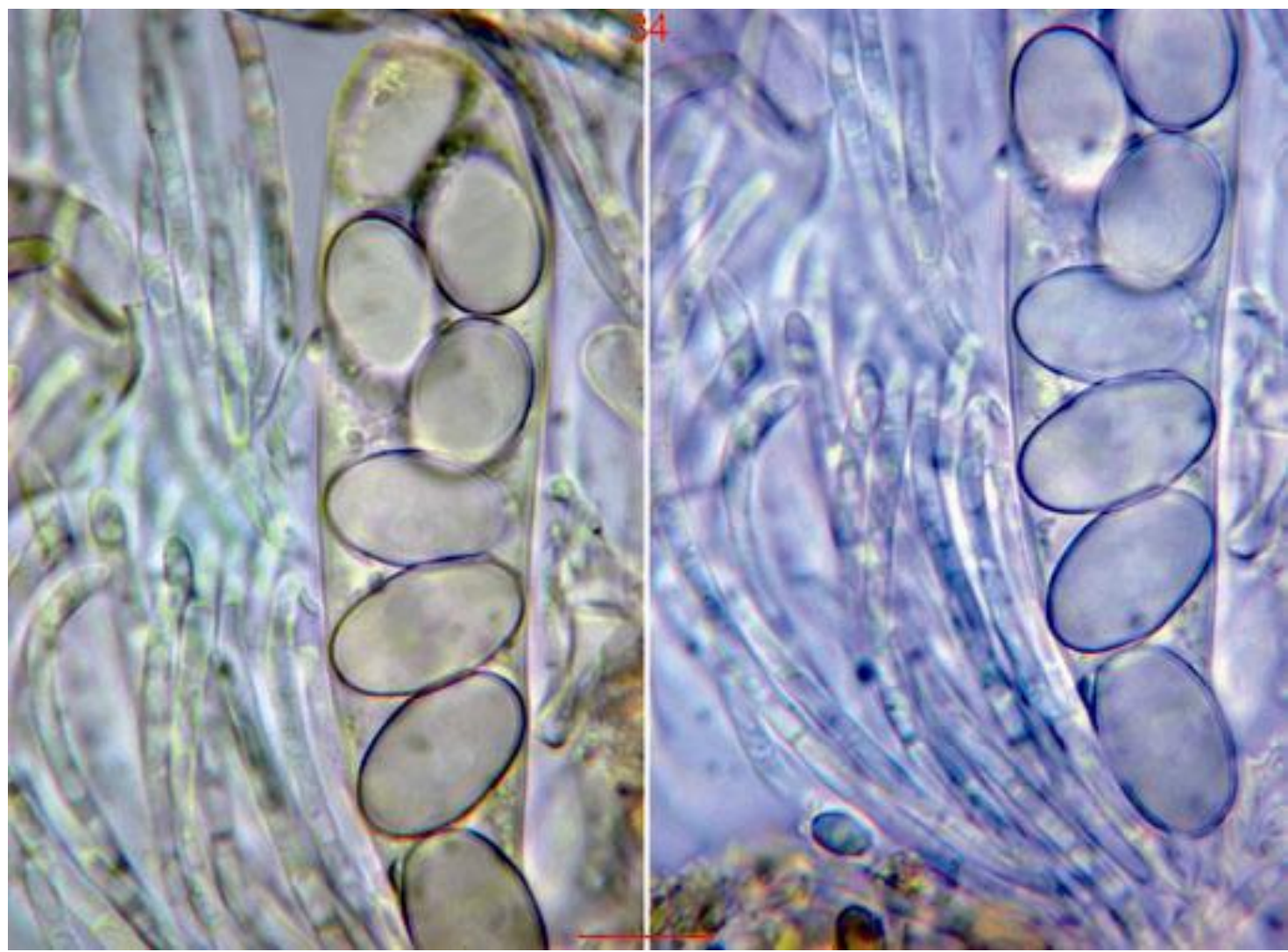

Figs 34 - Trichobolus dextrinoideosetosus. CLSM 00112bis. Paraphyses surrounding mature, 8spored asci with spores biseriate in the upper portion (water). Bar $=12 \mu \mathrm{m}$. 


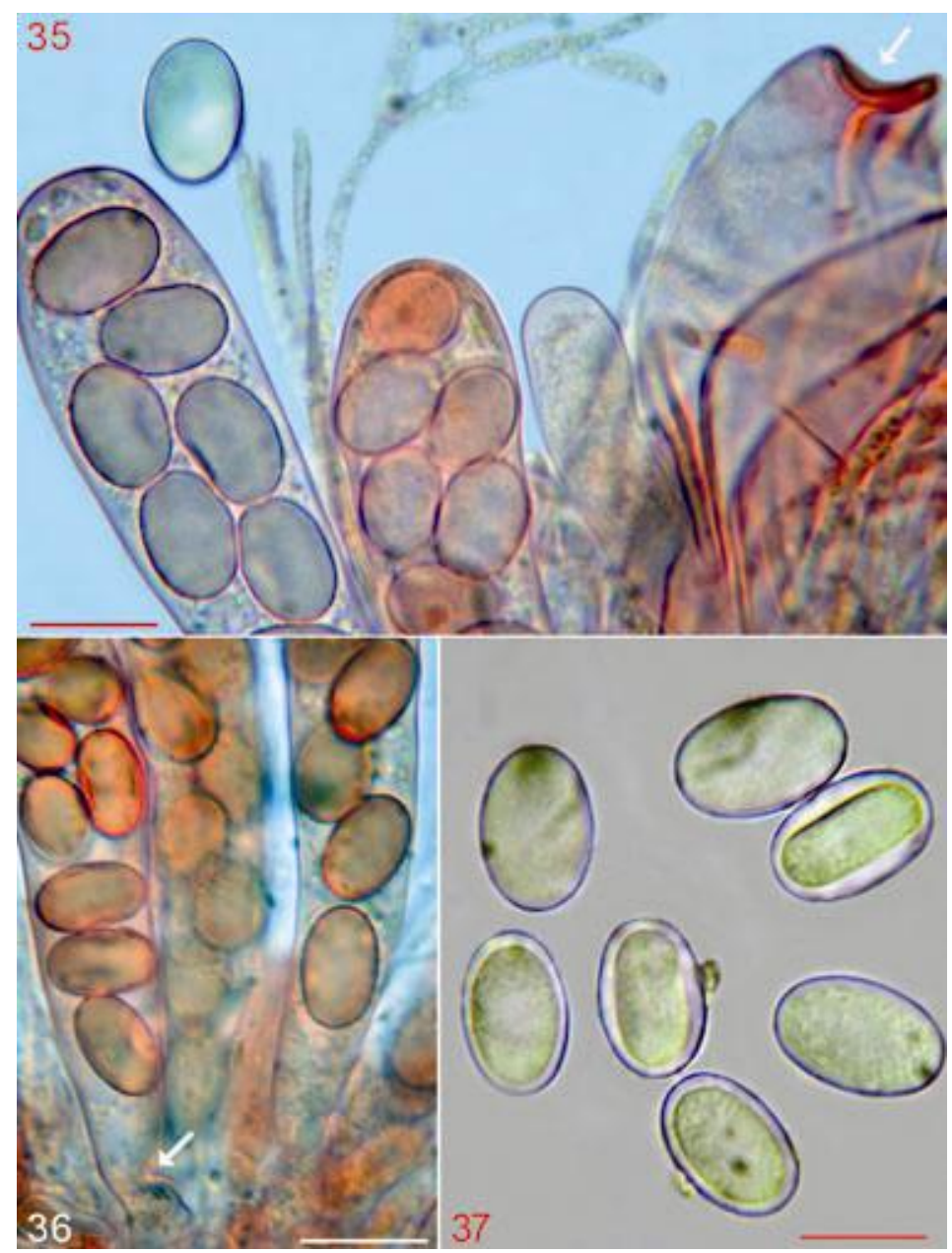

Figs 35-37 - Trichobolus dextrinoideosetosus. MCVE 27398. (35-36 = Congo red) 35 Paraphyses among operculate asci (arrow) 36 Asci with abruptly contracted bases (arrow) 37 Ascospores with yellowish contents (water). Bars 35-36 $=15 \mu \mathrm{m}, 37=10 \mu \mathrm{m}$.

Section Trichobolus included Thelebolus zukalii Heimerl $[=$ Trichobolus zukalii (Heimerl) Kimbr.], which shares with $\mathrm{Eu}-$ Thelebolus (Thelebolus stercoreus Tode : Fr., T. nanus Heimerl) growth on dung and minute, subspherical ascomata with a single, ovoidal, poly-spored ascus. Kimbough \& Cain (in Kimbrough \& Korf 1967) raised Trichobolus to genus rank in Theleboleae [ $=$ Thelebolaceae (Brumm.) Eckblad] and widened its definition placing T. pilosus (J. Schröt.) Kimbr., a species with three poly-spored asci and uniseptate setae, beside T. zukalii and T. sphaerosporus Kimbr., both uniascal and with polyseptate setae. In their concept Trichobolus is very close to Lasiobolus Sacc., with which it shares smooth ascospores usually with a de Bary bubble, and non-amyloid, congophilous asci, but Lasiobolus differs in having multiascal ascomata with operculate, cylindrical, $8-$ to poly-spored asci, ellipsoidal rather than spherical to broadly ellipsoidal ascospores, and ventricose, non-septate setae.

The establishment of Trichobolus octosporus (Krug 1973) further expanded the boundaries of the genus, which since then also encompasses a species with bowl-shaped ascomata, numerous, operculate, cylindrical, 8spored asci, scarcely septate (usually 1 septum, rarely $2-3$ ), sometimes non-septate setae, and a dextrinoid excipulum. These morphological features, including a dextrinoid reaction of the excipulum also observed in some Lasiobolus spp. (Krug 1973), place Trichobolus still closer to Lasiobolus, with the result that it is rather complex to separate the 8-spored species of the former from those of the latter. The differences appear to be restricted to the seta shape, which is usually ventricose and non-septate in Lasiobolus, simply enlarged and usually polymorphous at the base, and septate in Trichobolus. 

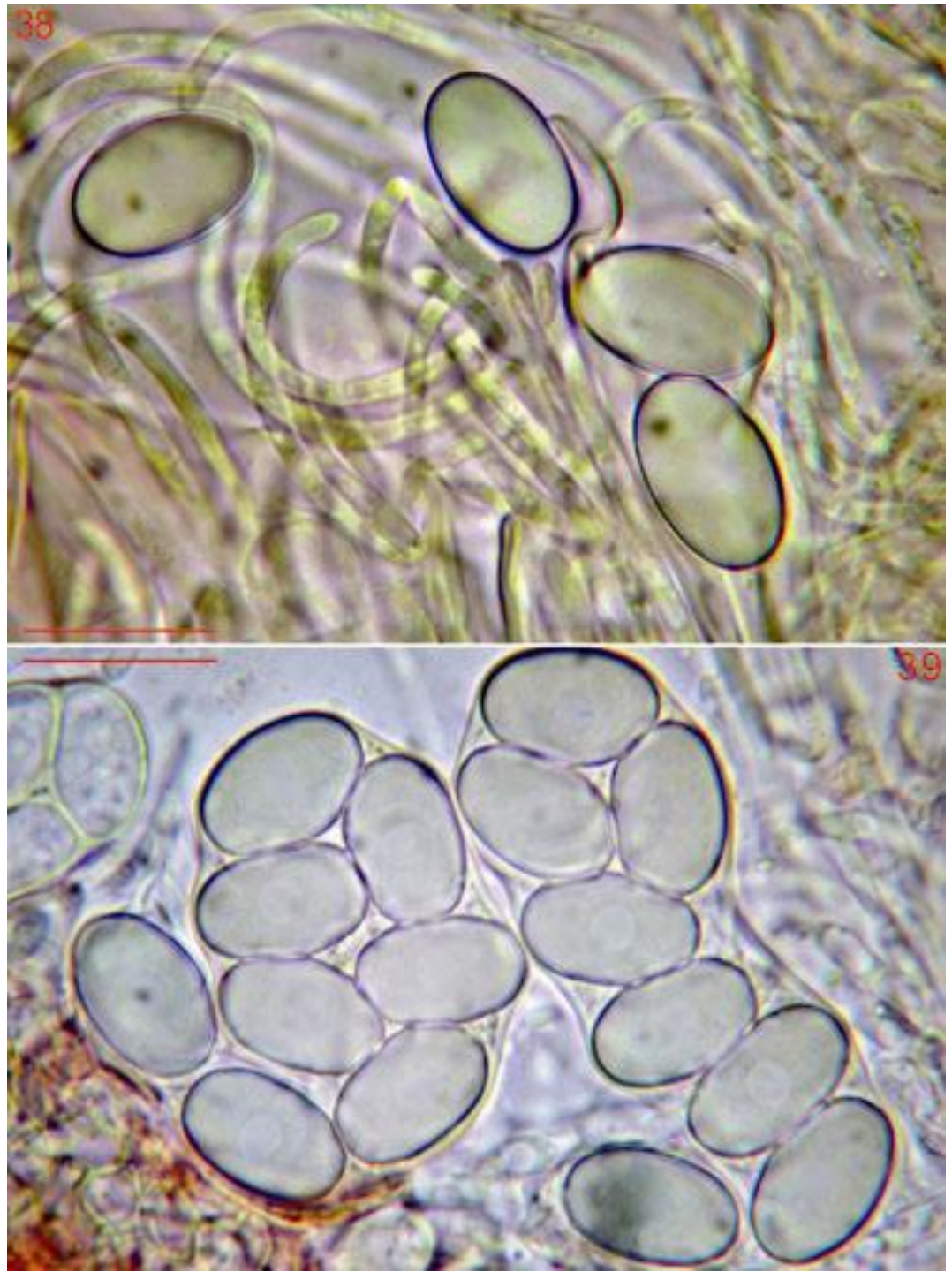

Figs 38-39 - Trichobolus dextrinoideosetosus. (water) 38 Free ascospores and paraphyses with yellowish contents (CLSM 00112bis) 39 Mature, uninucleate spores inside the asci (MCVE 27398). Bars $=38=18 \mu \mathrm{m}, 39=15 \mu \mathrm{m}$.

Doveri (2004) described T. octosporus from Italy, remarking that his collection from wild rabbit dung shows a spore size matching the protologue (collection from deer dung), but also broadly ellipsoidal, rarely subglobose ascospores $(\mathrm{Q}=1.08-1.26$; average $\mathrm{Q}=1.19)$ rather than "subspherical or occasionally subellipsoidal" (Q not mentioned in the original diagnosis). I have re-examined the specimens of this collection and taken some photos (Figs 40-46), which clearly prove its ascospores are less ellipsoidal than those drawn freehand in my previous work (Doveri 2004). They also prove that particularly the immature ascospores of my collection and those observed in polar view fully match the ascospores drawn in the protologue.
Doveri (2004) also confirmed the difficulty in distinguishing the 8-spored Trichobolus spp. from some Lasiobolus, particularly from L. trichoboloides R.S. Khan \& J.L. Bezerra, and provided a key which also included $T$. vanbrummelenii, the latest published 8-spored Trichobolus sp. (Valldosera \& Guarro 1988) after T. octosporus. Since then no new Trichobolus species has been erected.

The shallow-cupulate ascomata are the first useful feature to distinguish $T$. dextrinoideosetosus from the uniascal, polyspored species of Trichobolus. Other primary features of the new species are the operculate, 8 -spored asci, the ellipsoidal ascospores with a wide range of their size, and the strongly dextrinoid walls of setae and basal hyphoid 


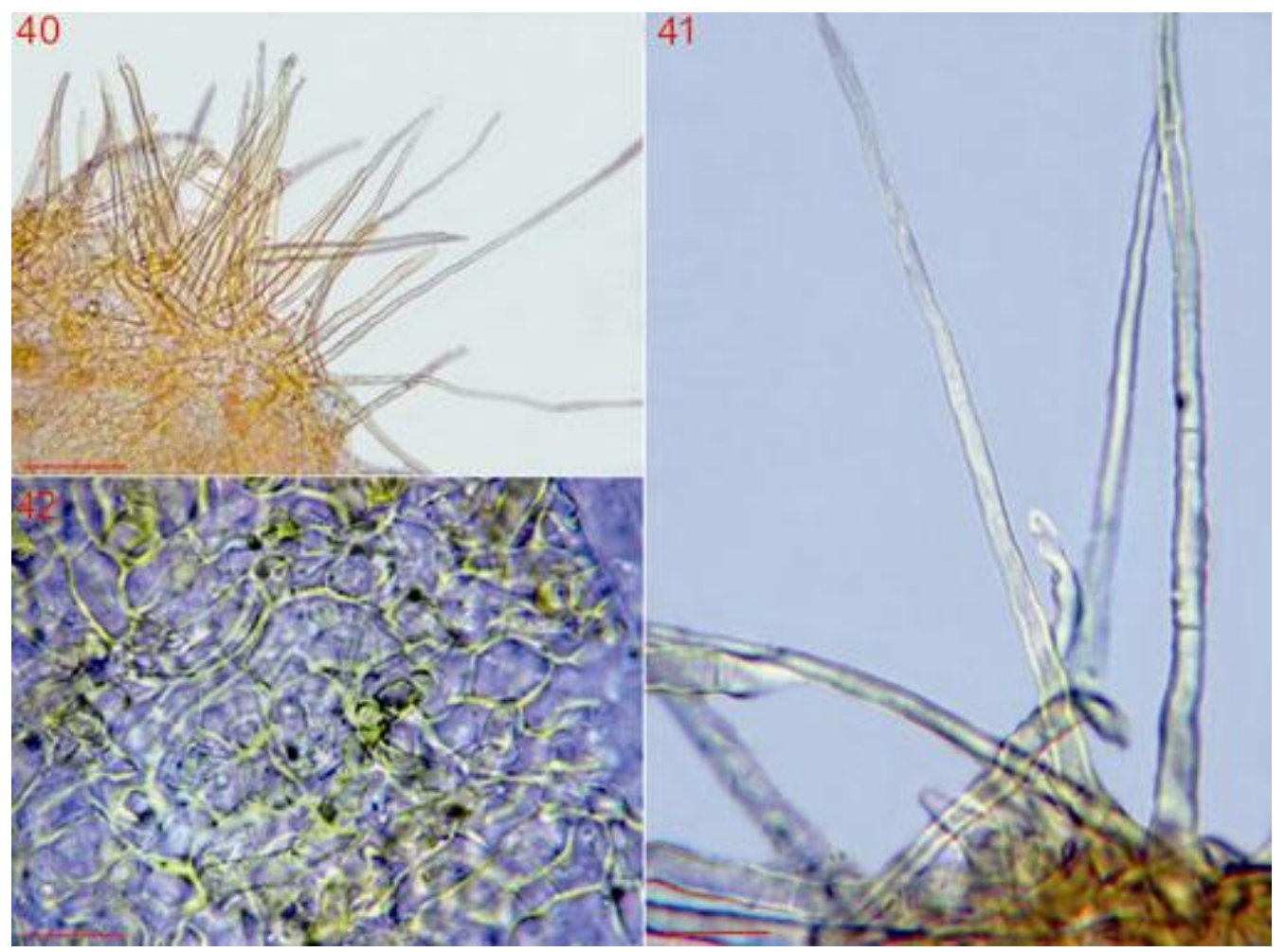

Figs 40-42 - Trichobolus octosporus. CLSM 06898. 40 Apical part of an ascoma with pointed setae 41 Setae 42 Detail of excipulum. Bars $40=40 \mu \mathrm{m}, 41=10 \mu \mathrm{m}, 42=15 \mu \mathrm{m}$.

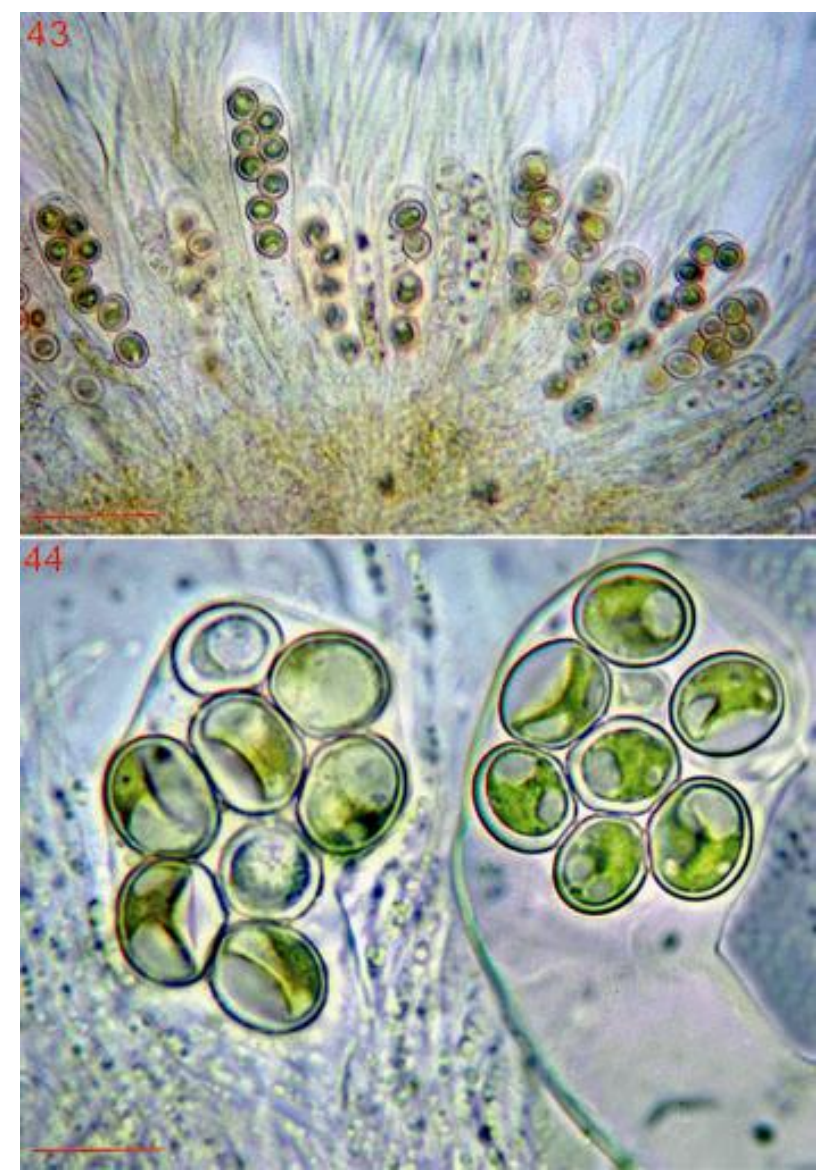

Figs 43-44 - Trichobolus octosporus. CLSM 06898. 43 Overall view of the hymenium 44 Subglobose to broadly ellipsoidal ascospores inside asci. Bars $43=40 \mu \mathrm{m}, 44=12 \mu \mathrm{m}$. 


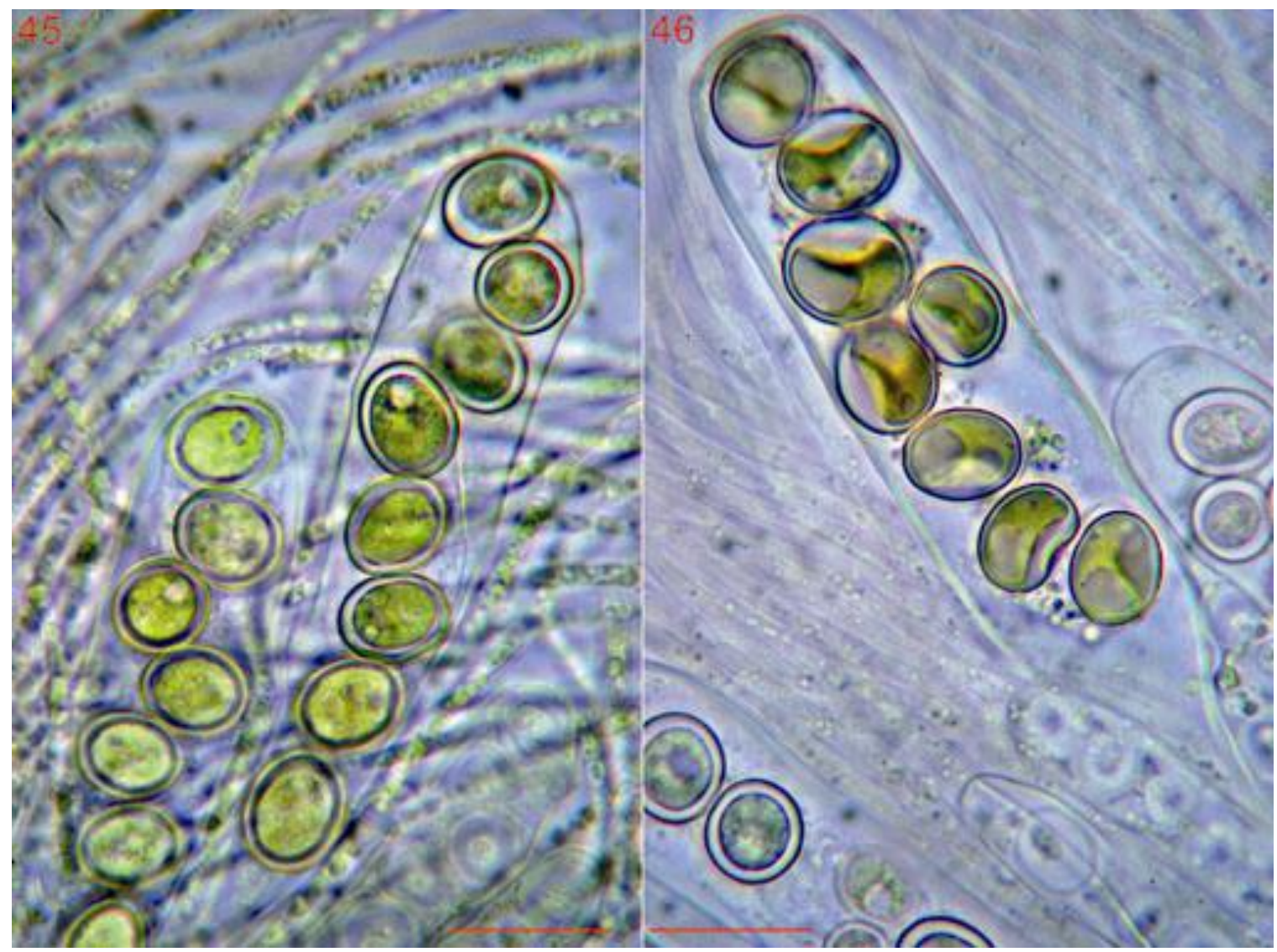

Figs 45-46 - Trichobolus octosporus. CLSM 06898. 45 Paraphyses overarching asci 46 Asci with spores in different stages of maturity. Bars $=15 \mu \mathrm{m}$.

hairs. The other two recognised Trichobolus spp. with 8-spored asci clearly differ from $T$. dextrinoideosetosus in having globose to subglobose ascospores (broadly ellipsoidal at most in T. octosporus), T. vanbrummelenii also in its ovoidal ascomata and asci (much more similar to those of the oligoascal, poly-spored species), and ascospores with a de Bary bubble (Valldosera \& Guarro 1988), T. octosporus also in having smaller $(12-13 \times 10-12 \mu \mathrm{m})$ ascospores. Unlike what I previously stated (Doveri 2004), the species described and drawn freehand by Prokhorov (1987) and Raitviir \& Prokhorov (1988) under T. octosporus is closer to, or even the same as my new species.

The ellipsoidal ascospores of $T$. dextrinoideosetosus place it even nearer to several 8-spored Lasiobolus spp. Only two species (L. monascus Kimbr., $L$. trichoboloides), however, have both septate (12 basal septa) and non-septate setae, like those of some Trichobolus spp.: the morphological features of L. monascus (Kimbrough 1974) are similar to the uniascal species of Trichobulus, whereas L. trichoboloides can be compared with $T$. dextrinoideosetosus as having similar minute, shallow-cupulate ascomata, narrow setae, cylindric-claviform asci, and ellipsoidal ascospores. But L. trichoboloides differs in having Lasiobolus-like setae (non- or uniseptate and with a subventricose base), smaller asci and ascospores $(8.5-11.5 \times 6-9 \mu \mathrm{m})$, and a constant rather than occasional textura prismatica at the margin, perpendicular to the hymenial surface (Bezerra \& Kimbrough 1975). Instead, I notice a greater likeness between T. dextrinoideosetosus and Lasiobolus cuniculi, but the latter has larger ascomata on average, longer and wider, subventricose, nonseptate setae, and basically larger ascospores (18-24 × 12-14 $\mu \mathrm{m}$, Bezerra \& Kimbrough 1975) with a de Bary bubble. Lasiobolus lasioboloides Marchal has a spore size and a seta shape and size similar to $T$. dextrinoideosetosus, but also broadly ellipsoidal or subglobose ascospores and nonseptate setae (Marchal 1885, Bezerra \& Kimbrough 1975). 
The wide range of the spore size in $T$. dextrinoideosetosus has been proven comparing my two Italian collections, the second of which, from wild rabbit dung, shows larger ascospores on average, (17-) 17.5-20.5 $(-21) \times(10.5-) 11-13 \mu \mathrm{m}$, mean $18.8 \times 11.7$ $(\mathrm{Q}=1.48-1.71 ; \mathrm{Q}=1.61)[34,3,1]$. The second collection has also asci up to $150 \mu \mathrm{m}$, and setae up to $250 \mu \mathrm{m}$ long, but an identical basic structure. As no gap in spore size between the two collections has been observed and the length/breadth ratio is practically the same, I firmly believe that both are representative of the new species.

The dextrinoid reaction of the excipulum has been observed in all Lasiobolus spp. (Bezerra \& Kimbrough 1975) and in Trichobo- lus octosporus (Krug 1973), but I have not seen it in T. dextrinoideosetosus. I have observed, on the contrary, strongly dextrinoid setae and hyphoid hairs in the new species, a feature that, as far as I know, has not been mentioned in any other Trichobolus or Lasiobolus sp., and that has influenced my choice of its specific name.

After Krug (1973) and Doveri (2004) I can conclude that $T$. dextrinoideosetosus belongs to a group of species which can be regarded as transitional forms between Trichobous and Lasiobolus, and I think that their still uncertain taxonomic position (van Brummelen 1998) possibly will be clarified through extensive phylogenetic studies. For the time being I think it useful to provide an updated key based on morphological features.

\section{Key to Trichobolus and similar species of Lasiobolus with 8-spored asci:}

1) Ascomata ovoidal or subglobose. Asci poly-spored, ovate to pyriform, 1-3 in number................2 $1^{*}$ ) Ascomata usually shallow-cupulate or bowl-shaped at maturity. Asci 8-spored, several in number.....

2) Asci 3 in number. Ascospores subglobose to broadly ellipsoidal. Setae with a basal septum. T. pilosus

$\left.2^{*}\right)$ Only 1 ascus in each ascoma. Setae usually poly-septate. 3

3) Ascospores globose or subglobose $(9-10 \times 8.5-9 \mu \mathrm{m}$; average $\mathrm{Q}=1.07$ in my Italian collections) .T. sphaerosporus

$\left.3^{*}\right)$ Ascospores subglobose to predominantly broadly ellipsoidal $(11.5-12.5 \times 9.5-10 \mu \mathrm{m}$; average $\mathrm{Q}=1.19$ in my Italian collections .T. zukalii

4) Ascomata and asci ovoidal. Ascospores spherical, 13-19 $\mu \mathrm{m}$ diam. Setae 2-5 septate. T. vanbrummelenii

4*) Ascomata more flattened at maturity. Asci cylindric-claviform. Ascospores different in shape.

5) Ascospores ellipsoidal (average $Q=>1.50$ )

5*) Ascospores subglobose to broadly ellipsoidal.

6) Ascospores 8.5-11.5 × 6-9 $\mu \mathrm{m}$ with a de Bary bubble. Setae non-septate or with a basal septum. Excipulum of a textura prismatica perpendicular to the hymenial surface. L. trichoboloides 6*) Ascospores larger. Excipulum occasionally and only partly of a textura prismatica......

7) Ascospores 18-24 $\times 12-14 \mu \mathrm{m}$, with a de Bary bubble. Setae subventricose, non-

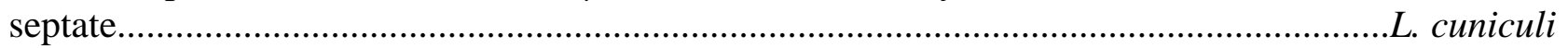

7*) Ascospores 14-20.5 × 9-13 $\mu \mathrm{m}$, without a de Bary bubble. Setae slightly enlarged at their polymorphous base, septate. T. Dextrinoideosetosus

8) Ascospores 12-13 × 10-12 $\mu \mathrm{m}$, without a de Bary bubble. Setae 0-3-septate. .T. octosporus 8*) Ascospores 13-18 × 9-13.5 $\mu \mathrm{m}$, with a de Bary bubble. Setae non-septate. .L. lasioboloides 


\section{Acknowledgements}

The author wishes to thank A. Bizzi and S. Rum for providing him part of the material subject of this study.

\section{References}

Abdullah SK, Alutbi SD. 1994 - Additions to coprophilous fungi of Iraq IV: the genera Coprotus and Lasiobolus: Pezizales. Abhath Al-Yarmouk 3, 55-63.

Bezerra JL, Kimbrough JW. 1975 - The genus Lasiobolus (Pezizales, Ascomycetes). Canadian Journal of Botany 53, 12061229. http://dx.doi.org/10.1139/b75-146

Brummelen J van. 1998 - Reconsideration of relationships within the Thelebolaceae based on ascus ultrastructure. Persoonia 16, 425-469.

Cacialli G, Caroti V, Doveri F. 1995 - Funghi fimicoli e rari o interessanti del litorale toscano. Schede di Micologia 1. A.M.B. Fondazione Centro Studi Micologici, Vicenza.

Cacialli G, Caroti V, Doveri F. 1996a Contributo allo studio dei funghi fimicoli-XIX. Prima segnalazione in Italia di Coprotus leucopocillum. Micologia e Vegetazione Mediterranea 11, 3-6.

Cacialli G, Caroti V, Doveri F. 1996b Contribución al estudio de los hongos coprófilos en Italia. XVI. Discomycetes: el Género Coprotus. Boletín de la Sociedad Micológica de Madrid 21, 113125.

Dissing H. 1980 - Chalazion helveticum (Pezizales), a new species from Graubünden, Switzerland. Sydowia 33, 29-32.

Dissing H, Sivertsen S. 1975 - Operculate Discomycetes from Rana (Norway) 1. Chalazion sociabile gen. nov., sp. nov. Norwegian Journal of Botany 22, 1-4.

Doveri F. 2004 - Fungi Fimicoli Italici. A.M.B. Fondazione Centro Studi Micologici, Vicenza.

Doveri F. 2011 - Addition to "Fungi Fimicoli Italici": An update on the occurrence of coprophilous Basidiomycetes and Ascomycetes in Italy with new records and descriptions. Mycosphere 2, 331-427.
Mycosphere Doi 10.5943/mycosphere/3/4/13

Doveri F, Wang Y.-Z, Cacialli G, Caroti V. 1998 - Una nuova specie di Chalazion dalla Toscana, Italia. Contributo allo studio dei funghi fimicoli - XXVIII. Rivista di Micologia 41, 203-209.

Doveri F, Cacialli G, Caroti V. 2000 - Guide pour l'identification des Pezizales fimicoles d'Italie. Documents Mycologiques 30(117-118), 3-97.

Holmgren PK, Holmgren NH. 1998 [continuously updated] - Index Herbariorum: A global directory of public herbaria and associated staff. New York Botanical Garden's Virtual Herbarium. http://sweetgum.nybg.org/ih/ [accessed July 2012]

Kimbrough JW. 1974 - Structure and development of Lasiobolus monascus, a new species of Pezizales, Ascomycetes. Mycologia 66, 907-918. http://dx.doi.org/10.2307/3758310

Kimbrough JW, Korf RP. 1967 - A synopsis of the genera and species of the tribe Theleboleae $(=$ Pseudoascoboleae $)$. American Journal of Botany 54, 9-23. http://dx.doi.org/10.2307/2440883

Kimbrough JW, Luck-Allen ER, Cain RF. 1972 - North American species of Coprotus (Thelebolaceae: Pezizales). Canadian Journal of Botany 50, 957-971. http://dx.doi.org/10.1139/b72-116

Krug JC. 1973 - An enlarged concept of Trichobolus (Thelebolaceae, Pezizales) based on a new eight-spored species. Canadian Journal of Botany 51, 14971501. http://dx.doi.org/10.1139/b73-189

Kutorga E. 2000 - Mycota Lithuaniae III, 5. Pezizales. Institutum Botanicae Lithuaniae Universitatis Vilnensis.

Lumbsch HT, Huhndorf SM. 2010 - Outline of Ascomycota 2009. Myconet 14, part one. Fieldiana n.s. 1, 1-64.

Marchal E. 1885 - Champignons coprophiles de Belgique. Mémoires de la Société Royale de Botanique de Belgique 24, 5777.

Moyne G. 2006 - Pezizomycetes (Discomycètes operculés) recoltes au cours de nos prospections dans le departement du Doubs (France). Bulletin de la Société d'Histoire Naturelle du Doubs 91, 115132. 
Moyne G, Petit J. 2006 - Quelques ascomycetes coprophiles recoltes en France et en particulier dans le departement du Doubs. Bulletin de la Société d'Histoire Naturelle du Doubs 91, 49-114.

Prokhorov VP. 1987 - Coprotrophic Discomycetes in Armenia. Mikologiya i Fitopatologia 21, 140-148.

Prokhorov VP. 1989 - The occurrence of Thelebolaceae in Estonia. Proceedings of the Estonian Academy of Sciences, Biology 1989, 38, 195-199.

Prokhorov VP. 1991 - Coprotrophic discomycetes from the Ukraine and Moldava. Ukrainian Botanical Journal 48, 34-41.

Prokhorov VP, Kutorga E. 1990 Coprophilous discomycetes in Lithuania and Latvia. Ekologija 4, 23-32.

Raitviir A, Prokhorov V. 1988 - Discomycetes of Middle Asia. IV. New data on Ascobolaceae and Thelebolaceae. Pro- ceedings of the Academy of Sciences of the Estonian SSR: Biology 37, 215-222.

Richardson MJ. 2001 - Diversity and occurrence of coprophilous fungi. Mycological Research 105, 387-402 http://dx.doi.org/10.1017/S09537562010 03884

Richardson MJ. 2008 - Coprophilous fungi from the Greek Aegean islands. Mycologia Balcanica 5, 23-32.

Richardson MJ, Watling R. 1997 - Keys to fungi on dung. British Mycological Society.

Saccardo PA. 1892 - Sylloge Fungorum Omnium Hucusque Cognitorum 10. Patavii.

Valldosera M, Guarro J. 1988 - Some coprophilous Ascomycetes from Chile. Transactions of the British Mycological Society 90 , 601-605. http://dx.doi.org/10.1016/S00071536(88)80065-2 